\title{
CAMA
}

Centre for Applied Macroeconomic Analysis

\section{Understanding the energy-GDP elasticity: A sectoral approach}

\section{CAMA Working Paper 45/2016 July 2016}

\section{Paul J. Burke}

Crawford School of Public Policy ANU and

Centre for Applied Macroeconomic Analysis, ANU

\section{Zsuzsanna Csereklyei}

Crawford School of Public Policy ANU

\begin{abstract}
This paper uses per capita data for 132 countries over 1960-2010 to estimate elasticities of sectoral energy use with respect to national gross domestic product (GDP). We estimate models in both levels and growth rates and use our estimates to sectorally decompose the aggregate energy-GDP elasticity. Our estimates show that residential energy use is very inelastic to GDP if primary solid biofuels are counted in energy use tallies, especially at low income levels. Residential use of electricity is more tightly linked to GDP, as is energy use by the transportation, industrial, and services sectors. Agriculture typically accounts for a small share of energy use and has a modest energyGDP elasticity. The aggregate energy-GDP elasticity tends to be higher for countries at higher income levels, in large part because traditional use of primary solid biofuels is less important. Gasoline prices, winter temperature, population, and land area are among other factors influencing sectoral energy use.
\end{abstract}




\section{Keywords}

elasticity, sectoral, energy use, economic development, economic growth, decomposition

\section{JEL Classification}

O13, Q43, O11

Address for correspondence:

(E) cama.admin@anu.edu.au

ISSN 2206-0332

The Centre for Applied Macroeconomic Analysis in the Crawford School of Public Policy has been established to build strong links between professional macroeconomists. It provides a forum for quality macroeconomic research and discussion of policy issues between academia, government and the private sector.

The Crawford School of Public Policy is the Australian National University's public policy school, serving and influencing Australia, Asia and the Pacific through advanced policy research, graduate and executive education, and policy impact. 


\section{Understanding the energy-GDP elasticity: A sectoral approach}

Paul J. Burke ${ }^{1 *}$ and Zsuzsanna Csereklyei ${ }^{1}$

${ }^{1}$ Australian National University, ACT 2601, Australia

* Corresponding author: paul.j.burke@anu.edu.au, +61 261256566

July 2016

This paper uses per capita data for 132 countries over 1960-2010 to estimate elasticities of sectoral energy use with respect to national gross domestic product (GDP). We estimate models in both levels and growth rates and use our estimates to sectorally decompose the aggregate energy-GDP elasticity. Our estimates show that residential energy use is very inelastic to GDP if primary solid biofuels are counted in energy use tallies, especially at low income levels. Residential use of electricity is more tightly linked to GDP, as is energy use by the transportation, industrial, and services sectors. Agriculture typically accounts for a small share of energy use and has a modest energy-GDP elasticity. The aggregate energyGDP elasticity tends to be higher for countries at higher income levels, in large part because traditional use of primary solid biofuels is less important. Gasoline prices, winter temperature, population, and land area are among other factors influencing sectoral energy use.

Keywords: elasticity, sectoral, energy use, economic development, economic growth, decomposition

JEL classifications: O13, Q43, O11

Acknowledgements: We are grateful for comments from three reviewers, David I. Stern, and seminar participants at Central European University, CNRS Université Pierre MendèsFrance, and the U.S. Energy Information Administration. 


\section{Introduction}

There has been longstanding interest in the energy-GDP elasticity - the \% change in energy use associated with a $1 \%$ change in gross domestic product (GDP). In early work this parameter was called the "energy elasticity" (Adams and Miovic, 1968) or the "energy coefficient” (Brookes, 1972; Ang, 1991). Other names are the income elasticity of energy use and the energy intensity of income growth (van Benthem, 2015). Using cross-sectional data, Csereklyei et al. (2016) recently reported that the mean long-run energy-GDP elasticity is around 0.7 , and that this has been quite stable over time.

In this paper we use per capita data for 132 countries to estimate elasticities of sectoral energy use with respect to GDP and use these to decompose the aggregate energy-GDP elasticity into sectoral contributions. While it is known that the sectoral composition of energy use evolves as economies develop (e.g. Nakićenović et al., 1998; Judson et al., 1999; Smil, 2000; Medlock and Soligo, 2001; Schäfer, 2005; Lescaroux, 2011; Arseneau, 2012), the contributions of end-use sectors to the aggregate energy-GDP elasticity are less well understood. Our estimates are potentially useful for energy planning and forecasting, particularly in rapidly-growing economies.

Our approach involves studying final energy use by five sectors - residences, agriculture (including fishing), transport, industry, and services - as well as other energy use not allocated to final energy use by these five sectors. We estimate both a levels model and a model in 10-year growth rates. In addition to energy-GDP elasticities we also present electricity-GDP elasticities by sector; if economic growth induces a relative shift toward electricity, electricity-GDP elasticities should exceed the energy-GDP elasticities. Our models will allow GDP elasticities to vary according to GDP per capita level.

Fig. 1 shows International Energy Agency (2016) data on per capita energy use by residences and the transport sector, plotted against GDP per capita. The data are for the 132 countries in our sample over the 51 years 1960-2010, with the Organisation for Economic Co-operation and Development (OECD23) shown separately. ${ }^{1}$ The energy use data include traditional energy forms such as primary solid biofuels. ${ }^{2}$ Quadratic best fits have been added. Because the Figure is in log-log space, the slopes are the unconditional mean energy-GDP elasticities evaluated at each GDP per capita level. The Figure reveals that at low and middle income levels, energy use by residences tends to fall and then slowly rise again as higher GDP per capita levels are reached. At high income levels, residential energy use is more closely tied to GDP. Energy use for transport is positively linked to GDP in quite a stable way across the income spectrum.

\footnotetext{
${ }^{1}$ We use OECD membership at the end of 1971, which covers 23 countries (“OECD23”), to avoid self-selection into the OECD based on economic performance over the later decades of the period. ${ }^{2}$ We use "traditional" to refer principally to primary solid biofuels, and "commercial" to refer to transitional and modern energy forms such as oil, coal, natural gas, and electricity. We recognize that divergences from these definitions exist. For example, solid biofuels can be traded commercially.
} 

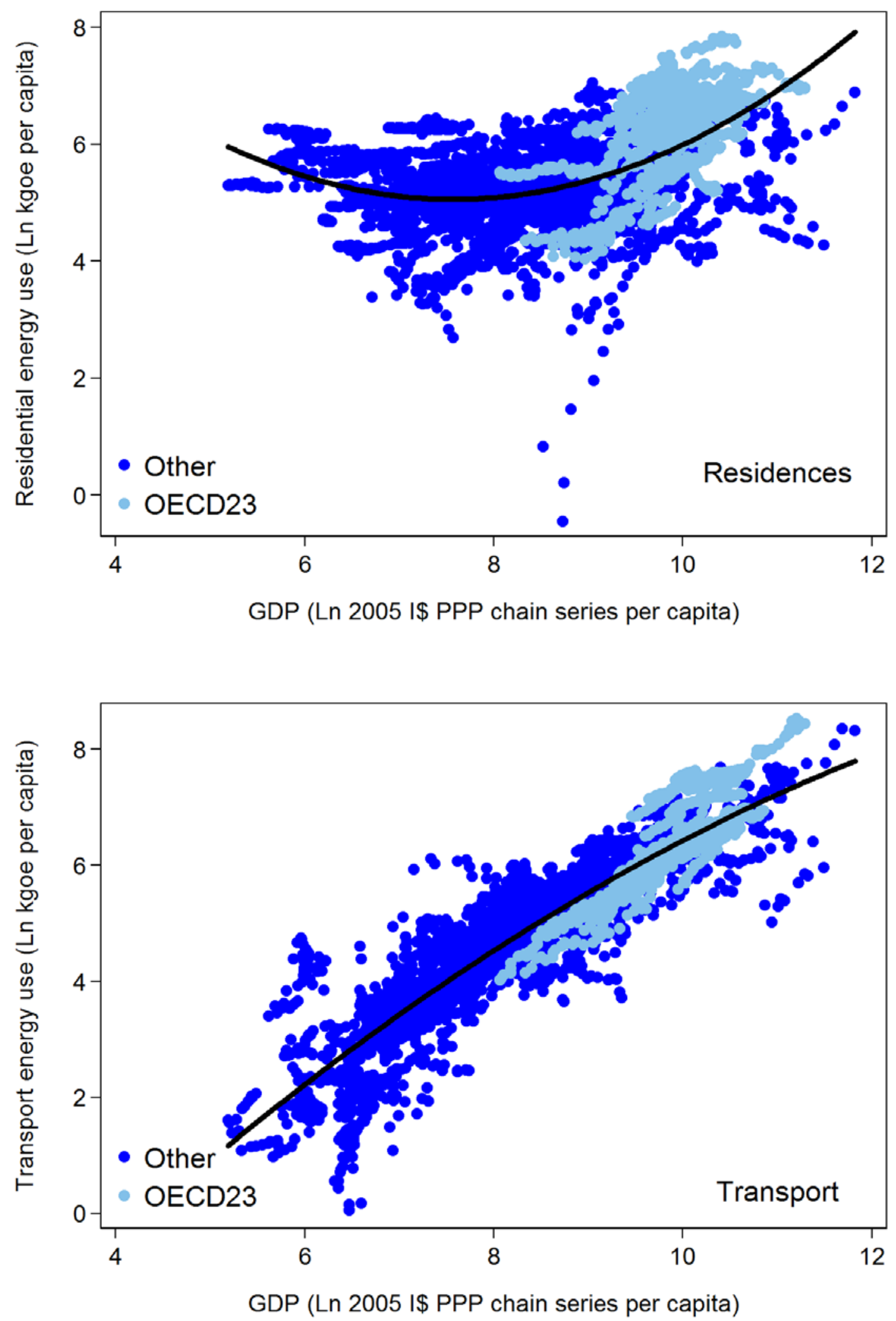

Fig. 1. Per capita final energy use for (a) residential purposes and (b) transport, by GDP per capita. Quadratic best fits have been added. Each dot is one of 4,840 annual observations from 132 countries over 1960-2010. Sources: Heston et al. (2012), International Energy Agency (IEA, 2016). 
It makes sense that the GDP elasticity of residential energy use is relatively low - and even negative - at low income levels. Households in low-income countries tend to depend on traditional energy sources such as primary solid biofuels, which are inefficient sources of energy. Household demand for traditional fuels might well have a negative income elasticity on account of their inferior status vis-à-vis transition and modern fuels. There may also be supply-side constraints on the use of traditional fuels. Residential use of commercial fuels is likely to have a higher GDP elasticity, and these fuels offer energy efficiency gains.

Economic growth in countries with low incomes might thus not induce sizeable increases in residential energy use measured in energy content terms, even if increases in the value of residential energy services are achieved (Adams and Miovic, 1968).

The evolution of sectoral energy use as economies develop is closely related to the evolution of sectoral output itself, early documentations of which were provided by Kuznets (1971) and Chenery and Syrquin (1975). Economic development typically sees economies transition from being dominated by agriculture, to becoming increasingly industrial, and then finally services-oriented. This pattern is to some extent reflected in energy use data also, although rather than agriculture it is residential energy use that dominates low-income energy profiles.

Among recent contributions, Jakob et al. (2012) estimated sectoral energy-GDP elasticities for 5-yearly growth rate panels of 21 OECD and 30 non-OECD countries, concluding that the effect of GDP growth on energy use may be smaller in OECD countries. For our large sample we instead find that energy-GDP elasticities actually tend to be higher at higher income levels, principally because traditional fuels play a smaller role in the energy mix. We obtain larger point estimates for the energy-GDP elasticity for OECD23 countries than for the nonOECD. That the energy-GDP elasticity is higher at higher GDP per capita has also been observed by, for example, van Benthem and Romani (2009) and Csereklyei and Stern (2015).

Among other recent work, Burke et al. (2015) report short-run sectoral and aggregate energyGDP elasticities, finding that the aggregate same-year elasticity is 0.4 , with a two-year elasticity of 0.5 . They report a higher same-year energy-GDP elasticity for OECD countries (0.6) than for non-OECD countries (0.4), but do not explore longer-term effects. Csereklyei and Stern (2015) and Csereklyei et al. (2016) report long-run elasticities that exceed the short-run effects estimated by Burke et al., but do not explore effects at the sectoral level. van Benthem (2015) presents sectoral energy-GDP elasticities for a sub-sample of countries, reporting a low elasticity for residential energy use for lighting, heating, and cooking.

Prior work has also examined how the fuel mix varies as economies develop, finding that countries typically transition from primary solid biomass to fossil fuels and then increasingly to nuclear power and/or modern renewables (Tahvonen and Salo, 2001; Burke, 2010, 2013). There are studies that examine energy use in a single sector or a group of sub-sectors (Miketa and Mulder, 2005; Adeyemi and Hunt, 2007, 2014; Lescaroux, 2013; Mulder et al., 2014; Gao et al., 2015). Previous research also documents energy intensity convergence among 
countries (e.g. Liddle, 2010; Herrerias, 2012; Mulder and de Groot, 2007, 2012). Our growth rates model will allow for sector-by-sector beta convergence in per capita energy use.

Our main contribution is to provide rigorous, up-to-date estimates of long-run and 10-year sectoral energy-GDP elasticities and demonstrate how these help in understanding the aggregate energy-GDP elasticity. Our study uses a long time dimension (1960-2010), broad geographical coverage (132 countries), and a broad definition of energy. While there are measurement issues for traditional fuels, it is important for these fuels to be considered given the large contribution they make to the energy mixes of many developing economies and our desire for broad geographical coverage. We will investigate the role of primary solid biofuels in explaining our results. The paper also explores potential heterogeneity among regions and country groupings.

Section 2 explains our approach. Section 3 provides the results. Section 4 concludes.

\section{Models and data}

We disaggregate the IEA (2016)'s primary energy use data into six categories: final energy use by (a) residences, (b) agriculture, (c) transport, (d) industry, and (e) services; as well as (f) all other energy use, a category that includes primary energy lost in transformation (e.g. the generation of electricity) and distribution; primary energy used by the energy industry; other final energy use not allocated to one of the above sectors; use of non-biomass fuels for non-energy purposes; and transfers and statistical differences. Using $E$ and $E^{F}$ for primary and final energy use per capita, the following applies:

$$
E=E_{R}^{F}+E_{A}^{F}+E_{T}^{F}+E_{I}^{F}+E_{S}^{F}+E_{O}
$$

where $R$ is residences, $A$ is agriculture, $T$ is transport, $I$ is industry, $S$ is services, and $O$ is other. The data allow a greater level of disaggregation if one wishes. For example, industry could be disaggregated into sub-sectors. Further disaggregation would, however, reduce our country coverage due to instances of $\ln (0)$. Data uncertainties are also often exacerbated at finer levels of disaggregation.

Year-2010 data for Eq. (1) are presented in Fig. 2 for low-, middle-, and high-income countries. The data show substantial inequality: per capita energy use tends to be much higher in countries with higher average incomes. The sectoral composition of energy use also varies across the income groups. 70\% of energy used by the low-income group is in the form of final energy consumed by residences. (It is not shown in the Figure, but nine-tenths of this is the use of primary solid biofuels such as wood.) Final energy use by residences accounts for only $13 \%$ of primary energy use in the high-income group, little of which is primary solid biofuels. Final energy use by the transport, services, and industry sectors increases substantially as one moves across the income groups. Agriculture is a relatively small energy user in all income groups, although we note that energy data do not include all energy inputs, such as sunlight energy used in photosynthesis. The "other" category accounts for $40 \%$ of primary energy use in both middle-income and high-income countries, and only $13 \%$ of 
primary energy use in the low-income group. This category mostly represents energy losses in transformation processes, principally electricity generation.

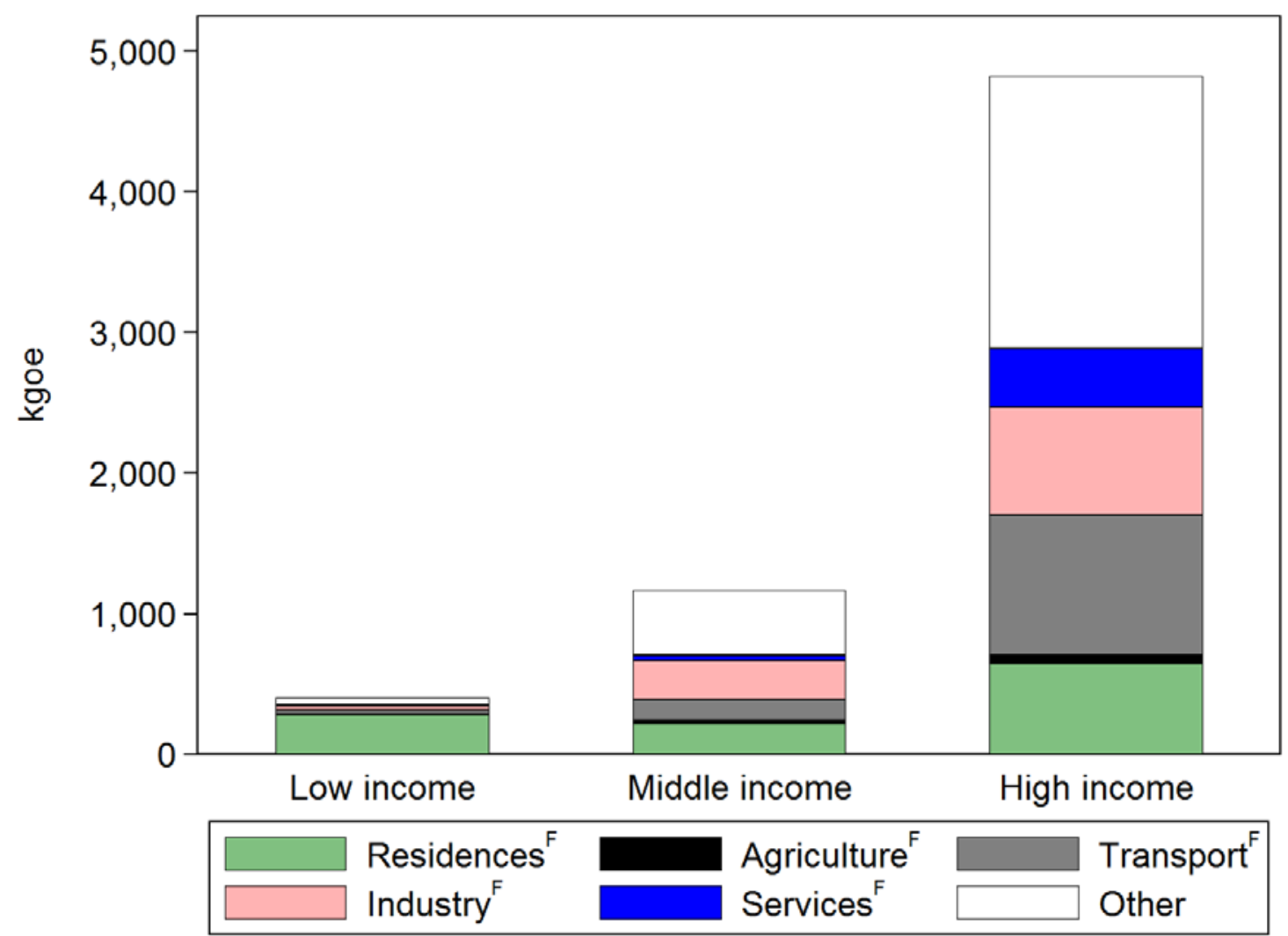

Fig. 2. Per capita energy use in 2010, by sector, for low-income, middle-income, and high-income countries. The data are population-weighted measures for the 132 countries in our sample (11 low income; 71 middle income; 50 high income). The F superscript means "final" energy use. The "other" category includes transformation losses and additional categories (see Appendix A1). Source: IEA (2016). Income groups are based on the World Bank (2015) definition.

Differentiating Eq. (1) by time ( $t$ ), dividing by $E$, and denoting $\mathrm{d} x / \mathrm{d} t$ by a dot over the variable $x$, we have:

$$
\frac{\dot{E}}{E}=\frac{E_{R}^{F}}{E} \frac{E_{R}^{F}}{E_{R}^{F}}+\frac{E_{A}^{F}}{E} \frac{\dot{E_{A}^{F}}}{E_{A}^{F}}+\frac{E_{T}^{F}}{E} \frac{E_{T}^{F}}{E_{T}^{F}}+\frac{E_{I}^{F}}{E} \frac{\dot{E_{I}^{F}}}{E_{I}^{F}}+\frac{E_{S}^{F}}{E} \frac{\dot{E_{S}^{F}}}{E_{S}^{F}}+\frac{E_{O}}{E} \frac{\dot{E_{O}}}{E_{O}}
$$

Dividing by the proportional real growth rate of GDP per capita in purchasing power parity (PPP) terms $(\dot{Y} / Y)$, and using $e_{E}$ to denote an energy-GDP elasticity:

$$
e_{E}=\frac{1}{E}\left(E_{R}^{F} \cdot e_{E_{R}^{F}}+E_{A}^{F} \cdot e_{E_{A}^{F}}+E_{T}^{F} \cdot e_{E_{T}^{F}}+E_{I}^{F} \cdot e_{E_{I}^{F}}+E_{S}^{F} \cdot e_{E_{S}^{F}}+E_{O} \cdot e_{E_{O}}\right)
$$

For small changes, the energy-GDP elasticity is thus the sum of the six sectoral energy-GDP elasticities, weighted by the sectoral share of total energy use. 
Our approach involves obtaining unweighted estimates of the six elasticities on the righthand side of Eq. (3). For example we estimate $e_{E_{R}^{F}}$, the GDP elasticity for the final energy use of residences. These elasticities are of interest in their own right. We then apply the weights to provide a simple sectoral decomposition of the energy-GDP elasticity. We use two types of model for estimating energy-GDP elasticities: a model in levels, and a model in growth rates.

\subsection{Levels estimates}

Our levels estimates use:

$$
\ln E_{s, c}^{F}=\alpha_{s}+\beta_{s} \ln Y_{c}+\gamma_{s}\left(\ln Y_{c}\right)^{2}+\mathbf{X}_{c}^{\prime} \boldsymbol{\delta}_{s}+\varepsilon_{s, c}
$$

where $E^{F}$ is final energy use per capita in sector $s$ of country $c, Y$ is real GDP per capita in PPP terms, $\mathbf{X}$ is a vector of controls, and $\varepsilon$ an error term. We use logs to produce coefficients that have an elasticity interpretation, and present estimates both with and without the quadratic term. When the quadratic is included, the energy-GDP elasticity is given by $\beta+2 \gamma \ln Y_{c}$, which means that it varies linearly with $\log$ GDP per capita if $\gamma \neq 0$. We also estimate Eq. (4) for total primary energy use $(E)$ and other energy use $\left(E_{O}\right)$. Our main levels estimates are for a year-2010 cross section. We also present between estimates for a panel dataset covering the period 1960-2010.

Our vector of controls includes the log gasoline price; the average temperature in the coldest and warmest months of the year; log annual precipitation; log population and log land, to measure scale effects; a dummy for former transition economies in Europe and Central Asia; and dummies for six regions (Sub-Saharan Africa, Middle East and North Africa, South Asia, Latin America and Caribbean, Europe and Central Asia, North America). The base region is East Asia and the Pacific. It should be noted that transition economies are covered by both the transition dummy and the Europe and Central Asia dummy.

The controls are likely to mostly be exogenous to sectoral energy use and not be channels through which a country's GDP affects energy use. A possible exception is the gasoline price, but we obtain nearly identical energy-GDP elasticities without this control. We avoid controlling for variables, such as trade openness, that may be influenced by GDP per capita. Our estimates are, however, similar when trade openness is controlled for. We expect the coefficients for log gasoline price and winter temperature to often be negative, as higher energy prices should reduce the quantity of energy demanded and cold weather increases heating requirements. A positive coefficient may in some instances be expected for summer temperature, as a warmer summer likely increases the demand for air conditioning. Because our regressions include the same control vector for each sector, seemingly unrelated regressions offer no advantage over an equation-by-equation approach.

Cross-sectional regressions use between variation, meaning that coefficients will have a longrun interpretation if variables are at long-run equilibria (Pesaran and Smith, 1995). The between estimator for our panel estimates uses the mean of each series over time in each 
country, which provides long-run effects while avoiding the need for specifying dynamics (Baltagi and Griffin, 1983, 1984; Pirotte, 1999, 2003; Baltagi, 2008). The between estimator is not affected by time-series issues related to unit roots (Stern, 2010) and has been found superior to alternative panel estimators in the presence of explanatory-variable measurement error (Hauk and Wacziarg, 2009).

\subsection{Growth rates estimates}

Our second estimation approach uses within variation from a model in 10-year growth rates. Advantages of the approach include that time-invariant level effects are removed by differencing; elements of the time series are used without introducing unit root issues; we are able to control for beta convergence and decade-specific time factors; and the estimates provide effects for the reasonably long window of 10 years, a period often relevant for forecasting and planning. Ordás Criado et al. (2011), Jakob et al. (2012), Anjum et al. (2014), and Csereklyei and Stern (2015) are among others to have previously estimated growth rate models of emissions and/or energy use.

We estimate the following model:

$$
\hat{E}_{s, c, t}^{F}=\left(\beta_{s}+\eta_{s} \ln \widetilde{Y}_{c, t-10}\right) \hat{Y}_{c, t}+\theta_{s} \ln Y_{c, t-10}+\kappa_{s} \ln E_{s, c, t-10}^{F}+\mathbf{X}_{s, t}^{\prime} \boldsymbol{\rho}_{s}+\pi_{s, t}+\varepsilon_{s, c, t}
$$

where hats indicate a 10-year average annual growth rate, calculated using e.g. $\hat{Y}=\left(\ln Y_{t}-\right.$ $\left.\ln Y_{t-10}\right) / 10$. The interaction between GDP per capita growth and $t-10 \log$ GDP per capita is included to allow the 10 -year energy-GDP elasticity to equal $\beta+\eta \widetilde{\ln Y} \widetilde{c t}_{c-10}$, i.e. to vary by $t-$ $10 \log$ GDP per capita. A positive $\eta$ would mean that the 10 -year elasticity is higher at higher $t-10 \log$ GDP per capita. A negative $\eta$ would mean that the impact of economic growth on energy use growth is lower at higher $t-10$ GDP per capita levels. The tilde $(\sim)$ indicates that we have subtracted the sample mean from this variable, implying that the 10-year energyGDP elasticity in a country with mean $t-10 \log$ GDP per capita is $\beta$. As for our levels estimates, we present results for $E_{O}$ and $E$ in addition to results for each final-use sector.

The long-run energy-GDP elasticity from Eq. (5), evaluated for a future GDP per capita growth rate of zero, is $-\theta / \kappa .^{3}$ The likely existence of lagged effects lead us to believe that long-run elasticities will exceed the 10-year elasticities. See De Boef and Keele (2008) for a review of dynamic models.

The inclusion of $t-10$ log energy use per capita in Eq. (5) allows for conditional beta convergence - the tendency for energy-intense economies to experience larger reductions in

\footnotetext{
${ }^{3}$ A generalized formula is $-(\theta+\eta x) / \kappa$, where $x$ is the average annual future per capita GDP growth rate. If $\eta>0$ and future GDP per capita growth is positive, our reported long-run elasticities will be underestimates, as they do not capture the amplified effect of future GDP per capita growth on per capita energy use growth at higher GDP per capita levels. Unreported simulations suggest, however, that it takes many decades before long-run effects differ substantially from 10-year effects.
} 
energy intensity, and for potential catch-up from below. For a discussion of other approaches to studying convergence, see Csereklyei et al. (2016). We follow the advice of Barro (2015) to not include country fixed effects in a model that has a convergence term, as doing so can introduce a mechanical correlation between the convergence term and the error (Hurwicz, 1950). Eq. (5) does, however, include decade time effects $\left(\pi_{s, t}\right)$ and the $\mathbf{X}$ vector of controls, for which we use period averages. We do not difference the controls, so their coefficients now measure effects on per capita energy use growth. We use the 2010 gasoline price, as data are not available for the full period. ${ }^{4}$

Our panel covers the decades to 1970, 1981, 1990, 2000, and 2010. The second period covers 1971-1981 as the IEA (2016) data commence in 1971 for most countries. The second and third periods thus have one year of overlap. In an additional specification we present estimates using 39-year growth rates (Appendix A5). Sectoral energy-GDP elasticities from 39-year estimates tend to be slightly larger than the elasticities from 10-year estimates.

The potential for reverse causality is a concern in both our levels and growth rates estimates, although, if energy prices are controlled for, the only genuine effect in the current literature appears to be that GDP causes energy use rather than vice versa (Bruns et al., 2014). ${ }^{5}$ Liddle and Lung (2015) also found that GDP Granger-causes sectoral energy use. Csereklyei and Stern (2015) presented a simple analysis of potential reverse causality bias in aggregate energy-GDP elasticities, finding that it is likely to be around +0.05 . We note that national GDP is likely to be less affected by energy use in an individual sector than it is by national energy use. While for these reasons reverse causality may not be a substantial issue for our estimates, the close interconnections between energy and GDP mean that our results should be interpreted as associations rather than unidirectional effects.

\subsection{Data}

The IEA (2016) energy use data, aggregated in tonnes of oil equivalent, are provided by national statistical agencies and other sources, and standardized by the IEA. They cover both commercial and non-commercial energy use. The data are not without measurement error. The IEA (2016) specifically cautions about the quality of the primary solid biofuels data, the time series of which is often estimated using simple modelling or interpolation/extrapolation. For this reason, and to obtain additional insights into the energy-GDP elasticity, we present results both including and excluding primary solid biofuels. Visual inspection of the energy use data for agriculture also reveals unrealistically large jumps in early years. We restrict our agriculture estimates to 1990-2010 to avoid these. The data for residences, agriculture, transport, industry, and services only cover final use of energy. The energy used in producing fertilizer and agricultural machinery is consequently allocated to industry rather than agriculture. The energy lost in transformation processes (e.g. electricity generation) is not passed through to sectoral end-users. It is included in $E_{O}$.

\footnotetext{
${ }^{4}$ We obtain similar results if we exclude this variable from our growth rate estimates.

${ }^{5}$ Bruns and Gross (2013) find that the results of electricity-GDP Granger causality tests are generally similar to energy-GDP Granger causality tests.
} 
Other data sources include Penn World Table 7.1 (Heston et. al., 2012) for GDP and population; Harris et al. (2014) for temperature and precipitation; the World Bank (2015) for land area, gasoline prices, and regional classifications; and Easterly (2001) for the dummy covering former transition economies. We chose version 7.1 of the Penn World Table as it covers more countries than versions 8.0 or 8.1. A list of variable definitions is in Appendix A1.

The (unbalanced) panel for our between estimates covers 4,840 observations from 132 countries over 1960-2010. A list of the countries is in Appendix A2. They accounted for 95\% of the world's population and primary energy consumption in 2010. The most populous countries excluded due to the non-availability of energy (and in some cases GDP) data are Myanmar, Uganda, Afghanistan, the Democratic Republic of Korea, and Madagascar. With the exception of Myanmar (middle income), these are low-income countries (World Bank, 2015).

Descriptive statistics are tabled in Appendix A3. Figs. 1-2 already showed that there is substantial variation in GDP per capita and sectoral energy use across countries, as should be expected. Our results tables will show standard errors that are robust to heteroskedasticity and, for our panel growth rate estimates, clustered by country to allow for possible countryby-country patterns of autocorrelation.

\section{Results}

\subsection{Levels results}

Cross-sectional estimates of Eq. (4) for the year 2010 are presented in Table 1. The estimates suggest that final per capita energy use by residences and agriculture are both relatively inelastic to GDP per capita, with mean elasticities of 0.33 and 0.50 . Transport (0.86), industry (0.88), and services (1.08) have larger mean energy-GDP elasticities. The elasticity for the "other" category is also high (0.98). The aggregate energy-GDP elasticity is 0.74 , similar to the estimates of Csereklyei et al. (2016). As shown by Eq. (3), this elasticity is a weighted average of the elasticities in columns 1-6.

The point estimates and 95\% confidence intervals from Table 1 are displayed in Fig. 3. The widest confidence interval is for agriculture, a sector for which data quality is likely to be relatively poor. The elasticities suggest that economic growth typically results in: (a) increased energy use; (b) increased energy use in each sector; (c) a reorientation of final energy use away from residences and agriculture, towards transport, industry, and services; and (d) a reduction in the energy intensity of the economy, as the energy-GDP elasticity is less than 1 . The relatively high coefficient for the "Other" category largely reflects the switch towards electricity as economies develop, as the transformation losses from electricity generation make up a large share of this category. 


\section{Table 1}

Levels estimates, 2010 cross-section and 1960-2010 panel between estimator.

Dependent variable: Ln per capita energy use by ...

\begin{tabular}{|c|c|c|c|c|c|c|c|}
\hline & $\begin{array}{l}\text { (1) } \\
\text { Residences }^{\mathrm{F}}\end{array}$ & $\begin{array}{l}\text { (2) } \\
\text { Agriculture }^{F}\end{array}$ & $\begin{array}{l}\text { (3) } \\
\text { Transport }^{\mathrm{F}}\end{array}$ & $\begin{array}{l}\text { (4) } \\
\text { Industry }^{\mathrm{F}}\end{array}$ & $\begin{array}{l}\text { (5) } \\
\text { Services }^{F}\end{array}$ & $\begin{array}{l}6) \\
\text { Other }\end{array}$ & $\begin{array}{l}(7) \\
\text { Total }\end{array}$ \\
\hline Ln GDP per capita & $\begin{array}{l}0.33^{* * *} \\
(0.08)\end{array}$ & $\begin{array}{l}0.50^{* *} \\
(0.23)\end{array}$ & $\begin{array}{l}0.86 * * * \\
(0.06)\end{array}$ & $\begin{array}{l}0.88^{* * *} \\
(0.10)\end{array}$ & $\begin{array}{l}1.08^{* * *} \\
(0.13)\end{array}$ & $\begin{array}{l}0.98^{* * *} \\
(0.08)\end{array}$ & $\begin{array}{l}0.74 * * * \\
(0.07)\end{array}$ \\
\hline Ln gasoline price & $\begin{array}{l}-0.12 \\
(0.10)\end{array}$ & $\begin{array}{l}0.61 * * * \\
(0.20)\end{array}$ & $\begin{array}{l}-0.22 * * * \\
(0.07)\end{array}$ & $\begin{array}{l}-0.28 * * * \\
(0.10)\end{array}$ & $\begin{array}{l}-0.24^{* *} \\
(0.12)\end{array}$ & $\begin{array}{l}-0.26^{* * *} \\
(0.08)\end{array}$ & $\begin{array}{l}-0.28^{* * *} \\
(0.05)\end{array}$ \\
\hline $\begin{array}{l}\text { Temperature (coldest } \\
\text { month) }\end{array}$ & $\begin{array}{l}-0.03^{* * *} \\
(0.01)\end{array}$ & $\begin{array}{l}-0.01 \\
(0.02)\end{array}$ & $\begin{array}{l}-0.01^{*} \\
(0.01)\end{array}$ & $\begin{array}{l}-0.02 \\
(0.01)\end{array}$ & $\begin{array}{l}-0.04 * * * \\
(0.01)\end{array}$ & $\begin{array}{l}-0.01 \\
(0.01)\end{array}$ & $\begin{array}{l}-0.01^{* *} \\
(0.01)\end{array}$ \\
\hline $\begin{array}{l}\text { Temperature (warmest } \\
\text { month) }\end{array}$ & $\begin{array}{l}0.01 \\
(0.02)\end{array}$ & $\begin{array}{l}-0.04 \\
(0.05)\end{array}$ & $\begin{array}{l}0.03 \\
(0.02)\end{array}$ & $\begin{array}{l}-0.01 \\
(0.02)\end{array}$ & $\begin{array}{l}0.04 \\
(0.04)\end{array}$ & $\begin{array}{l}0.01 \\
(0.03)\end{array}$ & $\begin{array}{l}0.00 \\
(0.02)\end{array}$ \\
\hline Ln precipitation & $\begin{array}{l}0.15 \\
(0.12)\end{array}$ & $\begin{array}{l}-0.10 \\
(0.27)\end{array}$ & $\begin{array}{l}0.16^{*} \\
(0.08)\end{array}$ & $\begin{array}{l}-0.08 \\
(0.15)\end{array}$ & $\begin{array}{l}0.16 \\
(0.20)\end{array}$ & $\begin{array}{l}-0.14 \\
(0.11)\end{array}$ & $\begin{array}{l}-0.07 \\
(0.08)\end{array}$ \\
\hline Ln Population & $\begin{array}{l}0.01 \\
(0.06)\end{array}$ & $\begin{array}{l}-0.16 \\
(0.14)\end{array}$ & $\begin{array}{l}-0.16^{* * *} \\
(0.04)\end{array}$ & $\begin{array}{l}-0.02 \\
(0.07)\end{array}$ & $\begin{array}{l}0.04 \\
(0.10)\end{array}$ & $\begin{array}{l}0.06 \\
(0.08)\end{array}$ & $\begin{array}{l}-0.03 \\
(0.05)\end{array}$ \\
\hline Ln Land & $\begin{array}{l}0.02 \\
(0.05)\end{array}$ & $\begin{array}{l}0.30 * * * \\
(0.09)\end{array}$ & $\begin{array}{l}0.13^{* * *} \\
(0.03)\end{array}$ & $\begin{array}{l}0.10 \\
(0.06)\end{array}$ & $\begin{array}{l}-0.08 \\
(0.09)\end{array}$ & $\begin{array}{l}-0.01 \\
(0.06)\end{array}$ & $\begin{array}{l}0.02 \\
(0.04)\end{array}$ \\
\hline Transition economy & $\begin{array}{l}-0.47 * * * \\
(0.16)\end{array}$ & $\begin{array}{l}-0.11 \\
(0.46)\end{array}$ & $\begin{array}{l}-0.18 \\
(0.13)\end{array}$ & $\begin{array}{l}0.02 \\
(0.21)\end{array}$ & $\begin{array}{l}-0.22 \\
(0.27)\end{array}$ & $\begin{array}{l}0.43^{*} \\
(0.23)\end{array}$ & $\begin{array}{l}-0.06 \\
(0.13)\end{array}$ \\
\hline Europe \& Central Asia & $\begin{array}{l}0.54 * * * \\
(0.17)\end{array}$ & $\begin{array}{l}-0.02 \\
(0.41)\end{array}$ & $\begin{array}{l}0.21 \\
(0.13)\end{array}$ & $\begin{array}{l}-0.38^{*} \\
(0.20)\end{array}$ & $\begin{array}{l}0.14 \\
(0.26)\end{array}$ & $\begin{array}{l}-0.48^{* *} \\
(0.21)\end{array}$ & $\begin{array}{l}-0.14 \\
(0.13)\end{array}$ \\
\hline $\begin{array}{l}\text { Latin America \& } \\
\text { Caribbean }\end{array}$ & $\begin{array}{l}-0.02 \\
(0.18)\end{array}$ & $\begin{array}{l}-0.24 \\
(0.38)\end{array}$ & $\begin{array}{l}-0.06 \\
(0.17)\end{array}$ & $\begin{array}{l}-0.24 \\
(0.20)\end{array}$ & $\begin{array}{l}-0.18 \\
(0.25)\end{array}$ & $\begin{array}{l}-0.62 * * * \\
(0.21)\end{array}$ & $\begin{array}{l}-0.38^{* * *} \\
(0.12)\end{array}$ \\
\hline Middle East \& North & $\begin{array}{l}0.39 \\
(0.35)\end{array}$ & $\begin{array}{l}0.30 \\
(080)\end{array}$ & $\begin{array}{l}0.40^{* *} \\
(0.19)\end{array}$ & $\begin{array}{l}-0.39 \\
(0.36)\end{array}$ & $\begin{array}{l}-0.39 \\
(0.64)\end{array}$ & -0.31 & -0.24 \\
\hline $\begin{array}{l}\text { AIrIca } \\
\text { North America }\end{array}$ & $\begin{array}{l}0.35 * * \\
(0.15)\end{array}$ & $\begin{array}{l}(0.80) \\
-0.59 \\
(0.49)\end{array}$ & $\begin{array}{l}0.56 * * * \\
(0.15)\end{array}$ & $\begin{array}{l}-0.93 * * * \\
(0.23)\end{array}$ & $\begin{array}{l}(0.64) \\
0.44 \\
(0.31)\end{array}$ & $\begin{array}{l}(0.30) \\
-0.33 \\
(0.22)\end{array}$ & $\begin{array}{l}(0.20) \\
-0.09 \\
(0.13)\end{array}$ \\
\hline South Asia & $\begin{array}{l}0.25 \\
(0.28)\end{array}$ & $\begin{array}{l}-0.72 \\
(0.72)\end{array}$ & $\begin{array}{l}-0.34 \\
(0.20)\end{array}$ & $\begin{array}{l}-0.37 \\
(0.31)\end{array}$ & $\begin{array}{l}-0.56 \\
(0.34)\end{array}$ & $\begin{array}{l}-1.24^{* *} \\
(0.48)\end{array}$ & $\begin{array}{l}-0.38^{* *} \\
(0.17)\end{array}$ \\
\hline Sub-Saharan Africa & $\begin{array}{l}0.85 * * * \\
(0.30)\end{array}$ & $\begin{array}{l}-1.61^{* * *} \\
(0.59)\end{array}$ & $\begin{array}{l}-0.09 \\
(0.17)\end{array}$ & $\begin{array}{l}-0.53^{*} \\
(0.28)\end{array}$ & $\begin{array}{l}0.21 \\
(0.37)\end{array}$ & $\begin{array}{l}-0.03 \\
(0.27)\end{array}$ & $\begin{array}{l}0.16 \\
(0.19)\end{array}$ \\
\hline$R^{2}$ & 0.56 & 0.60 & 0.91 & 0.79 & 0.73 & 0.83 & 0.87 \\
\hline $\begin{array}{l}\text { Observations } \\
\text { Panel between estimate } \\
\text { for Ln GDP per capita }\end{array}$ & $\begin{array}{l}132 \\
0.37 * * *\end{array}$ & $\begin{array}{l}114 \\
0.57 * * *\end{array}$ & $\begin{array}{l}132 \\
0.95 * * *\end{array}$ & $\begin{array}{l}132 \\
0.93 * * *\end{array}$ & $\begin{array}{l}130 \\
1.16^{* * * *}\end{array}$ & $\begin{array}{l}132 \\
1.01 * * *\end{array}$ & $\begin{array}{l}132 \\
0.78 * * *\end{array}$ \\
\hline $\begin{array}{l}\text { Notes: ***, **, and * in } \\
\text { The samples in column } \\
\text { Coefficients on constan } \\
\text { observations from } 132\end{array}$ & $\begin{array}{l}\text { statistic } \\
\text { d } 5 \text { are re } \\
\text { shown. }\end{array}$ & $\begin{array}{l}\text { nificance } \\
\text { due to in }\end{array}$ & $\begin{array}{l}\text {, and } 10 \\
\text { es of } \ln ( \\
\text { es are fo } \\
\text { ude the }\end{array}$ & $\begin{array}{l}\text { Robust s } \\
\text { he base }\end{array}$ & $\begin{array}{l}\text { ard err } \\
\text { lon is } \mathrm{E} \\
\text { hat cor }\end{array}$ & $\begin{array}{l}\text { in pa } \\
\text { ia an } \\
\text { to } 4,8 \\
\text { es for }\end{array}$ & $\begin{array}{l}\text { Peses. } \\
\text { Pacific. } \\
\text { ulture }\end{array}$ \\
\hline
\end{tabular}

The results on the other variables in Table 1 are of interest. Higher road-sector gasoline prices are associated with less energy use, consistent with a negative price elasticity of demand (Burke and Nishitateno, 2013). An exception is agriculture, perhaps because higher fuel prices discourage industrialization. Colder winters are associated with more energy use in several sectors including residences, a logical result given the higher heating requirements in colder climates. The estimates provide no evidence that summer temperature or annual precipitation significantly influence sectoral or total energy use at the $5 \%$ significance level. ${ }^{6}$ Densely populated countries tend to use less energy for transport, which makes sense as domestic travel

\footnotetext{
${ }^{6}$ In our 39-year growth rates estimates we find that residential and service-sector electricity use have grown faster in countries with warmer summers. See Appendix A5.
} 
distances are shorter. ${ }^{7}$ Countries with more land tend to use more energy for agriculture, likely to be because they have more space for farms.

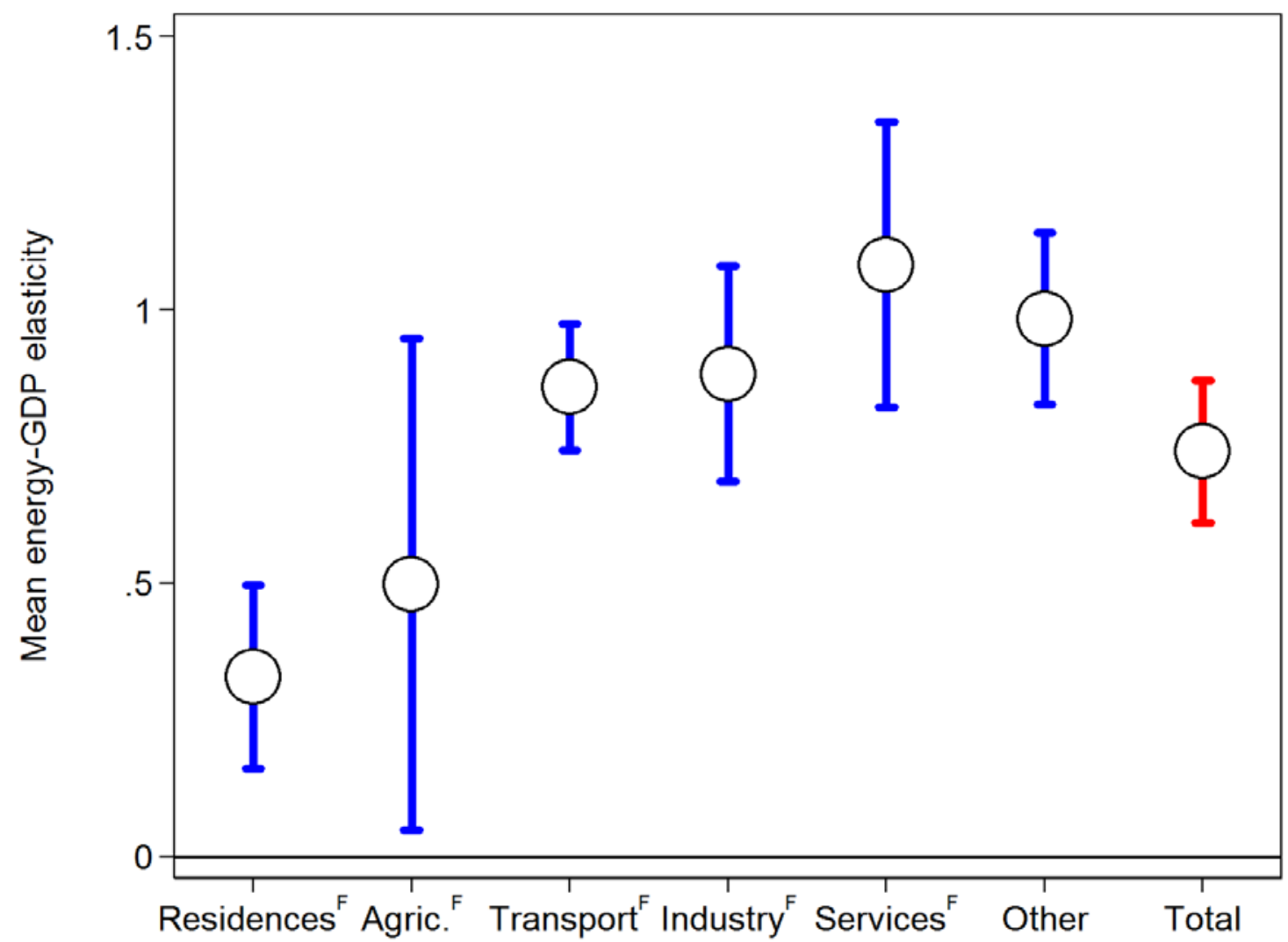

Fig. 3. Mean long-run energy-GDP elasticities from levels regressions, 2010. These are the conditional effects from Table 1. Both point estimates and 95\% confidence intervals are shown. All estimates differ from zero at $5 \%$ significance (see Table 1). All except the industry, services, and other estimates differ from unity at $5 \%$ significance.

The region and transition dummies also reveal interesting information. Sub-Saharan African countries report low energy use in agriculture, likely due to relatively unmechanized production. On the other hand Sub-Saharan Africa countries use a relatively large amount of energy at the residential level for countries at their GDP per capita levels, presumably due to high reliance on energy-inefficient biomass combustion. Holding other variables fixed, countries in (a) South Asia and (b) Latin America and the Caribbean tend to use less energy, particularly in the "Other” category. Countries outside East Asia and the Pacific often devote less energy to industrial production, consistent with a lower average industry share of GDP. ${ }^{8}$ North American countries tend to use more energy at the residential level and for transport, and less for industrial production. Europe and Central Asia countries outside the group of former transition economies also use a disproportionate amount of energy at the residential level. This is probably in part caused by climate factors not fully picked up by our controls,

\footnotetext{
${ }^{7}$ We control for log land, so the coefficient for log population is the effect of log population density.

${ }^{8}$ The average share of industrial value-added in GDP in 2010 was 35\% among East Asia and the Pacific economies in our sample, and 31\% among other countries (World Bank, 2015).
} 
such as the length of winters. The transition economies use less energy at the residential level than other countries in Europe and Central Asia, and more “Other” energy.

The $R^{2}$ values in Table 1 are high. The variables account for $56 \%$ of the variation in log residential energy use per capita in 2010, and up to $91 \%$ of the variation in log transport energy use per capita.

Between estimates for our 1960-2010 panel are shown in the base of Table 1, and in more detail in Appendix A4. The estimations include the controls, but to save space we do not report their coefficients. The elasticities are similar: residential and agricultural energy use are relatively inelastic to GDP (elasticities of 0.37 and 0.57 ), whereas transport, industry, and services have energy-GDP elasticities closer to unity. The average energy-GDP elasticity is 0.78, similar to the cross-sectional estimate for 2010. 2010 is thus not an unusual year; the cross-sectional relationships are relatively stable.

Table 2 presents cross-sectional estimates for 2010 with the squared log GDP per capita term. The table also shows the implied energy-GDP elasticity point estimates at the $25^{\text {th }}, 50^{\text {th }}$, and $75^{\text {th }}$ percentiles of GDP per capita. The estimates include the vector of controls, but to save space we do not show the coefficients. The Table confirms that per capita sectoral energy use is generally positively associated with per capita GDP. An exception is for residences at low GDP per capita levels, where the GDP elasticity is close to zero and, in point-estimate terms, even becomes negative at GDP per capita levels less than \$1,600 (as also seen in Fig. 1). This can be explained by high dependence on primary solid biofuels: residential use of these fuels tends to decrease as incomes increase, as we will soon see. Residential use of other fuels tends to increase, and these other fuels can be used more efficiently. That middle-income countries tend to use less energy at the residential level can be observed in Fig. 2.

The statistical significance of the quadratic term in column 7 of Table 2 indicates that the aggregate energy-GDP elasticity tends to be higher at higher GDP per capita. The point estimates of the energy-GDP elasticity equal 0.63 at the $25^{\text {th }}$ percentile of GDP per capita, increasing to 1.04 at the $75^{\text {th }}$ percentile. Some sectoral energy-GDP elasticities are themselves also higher at higher GDP per capita, most notably the elasticity for residences. The existence of a strictly convex pattern in the log-log energy-GDP relationship - an increasing energy-GDP elasticity - is demonstrated in Panel A of Fig. 4.

Table 3 presents estimates that exclude primary solid biofuels. As expected, the mean energyGDP elasticities are now generally larger, especially for residences (0.59) and in total (0.95). This is consistent with economic growth inducing an energy-mix switch away from primary solid biofuels. Table 3 provides no strong evidence that the GDP elasticity for commercial fuels is higher for countries at higher GDP per capita levels. That the energy-GDP elasticity excluding primary solid biofuels is relatively stable across different GDP per capita levels can also be seen in Panel B of Fig. 4. 
Table 2

Levels estimates with the quadratic, 2010.

Dependent variable: Ln per capita energy use by ...

\begin{tabular}{|c|c|c|c|c|c|c|c|}
\hline & (1) & (2) & (3) & (4) & (5) & (6) & (7) \\
\hline & Residences $^{F}$ & Agriculture $^{\mathrm{F}}$ & Transport $^{\mathrm{F}}$ & Industry $^{\mathrm{F}}$ & Services $^{F}$ & Other & Total \\
\hline \multirow[t]{2}{*}{ Ln GDP per capita } & $-1.85 * * *$ & 0.28 & $1.19 * *$ & -0.79 & 0.50 & 0.52 & $-1.20 * *$ \\
\hline & $(0.55)$ & (3.88) & $(0.48)$ & $(1.05)$ & $(1.60)$ & $(0.75)$ & $(0.49)$ \\
\hline \multirow[t]{2}{*}{$(\text { Ln GDP per capita) })^{2}$} & $0.12 * * *$ & 0.01 & -0.02 & $0.10^{*}$ & 0.03 & 0.03 & $0.11 * * *$ \\
\hline & $(0.03)$ & $(0.21)$ & $(0.03)$ & $(0.06)$ & $(0.09)$ & $(0.04)$ & $(0.03)$ \\
\hline Controls and region dummies & Yes & Yes & Yes & Yes & Yes & Yes & Yes \\
\hline Energy-GDP relationship is: & $\begin{array}{l}\text { U (turning point } \\
\text { at } \$ 1,622)\end{array}$ & Positive & Positive & Positive & Positive & Positive & Positive \\
\hline \multicolumn{8}{|c|}{ Elasticity evaluated at $x^{\text {th }}$ percentile of GDP per capita... } \\
\hline $25^{\text {th }}$ & $0.20 * *$ & 0.49 & $0.88 * * *$ & $0.78 * * *$ & $1.05^{* * *}$ & $0.96 * * *$ & $0.63^{* * *}$ \\
\hline $50^{\text {th }}$ & $0.44 * * *$ & $0.51 * * *$ & $0.84 * * *$ & $0.97 * * *$ & $1.11^{* * *}$ & $1.01 * * *$ & $0.84 * * *$ \\
\hline $75^{\text {th }}$ & $0.66 * * *$ & 0.53 & $0.81^{* * *}$ & $1.14^{* * *}$ & $1.17 * * *$ & $1.05 * * *$ & $1.04 * * *$ \\
\hline$R^{2}$ & 0.63 & 0.60 & 0.91 & 0.81 & 0.73 & 0.83 & 0.90 \\
\hline Observations & 132 & 114 & 132 & 132 & 130 & 132 & 132 \\
\hline
\end{tabular}

Notes: ${ }^{* * *},{ }^{* *}$, and * indicate statistical significance at 1,5, and 10\%. Robust standard errors are in parentheses. The samples in columns 2 and 5 are reduced due to instances of $\ln (0)$. The GDP per capita percentiles are for the full sample. The energy-GDP relationship is only classed as $U$ or inverse $U$ if the quadratic term is statistically significant and GDP per capita at the turning point exceeds $\$ 1,000$ and is less than $\$ 100,000$. Coefficients for controls and region dummies not shown. 

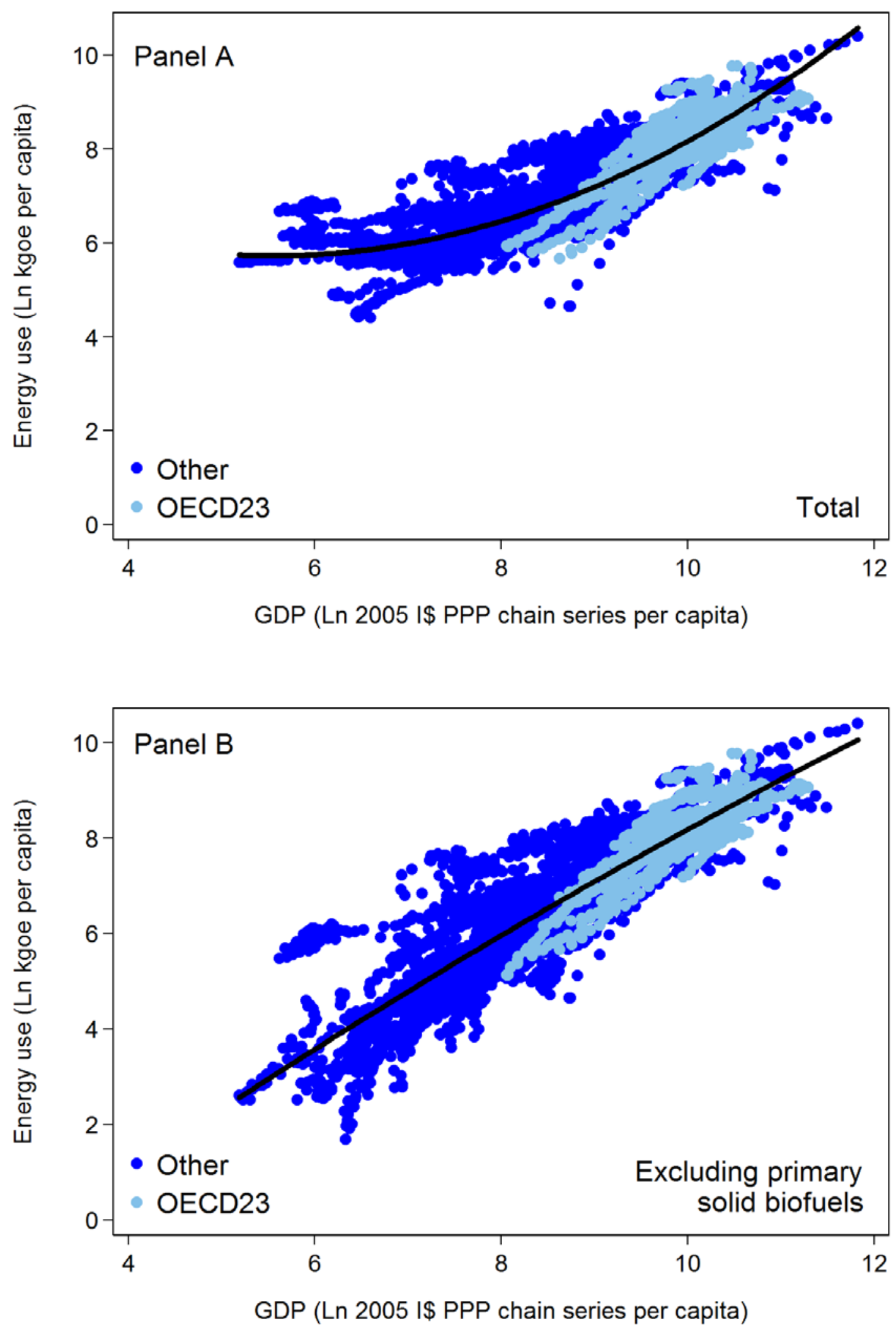

Fig. 4. Primary energy use per capita, with and without primary solid biofuels, by GDP per capita. Quadratic best fits have been added. Each dot is one of 4,840 annual observations from 132 countries over 1960-2010. The lighter dots are the OECD23. The exclusion of primary sold biofuels mostly affects the left-hand-side of the distribution. Sources: Heston et al. (2012), IEA (2016). 


\section{Table 3}

Levels estimates for energy use excluding primary solid biofuels, 2010.

Dependent variable: Ln per capita use of energy ...

\begin{tabular}{|c|c|c|c|c|c|c|c|}
\hline & (1) & (2) & (3) & (4) & (5) & (6) & (7) \\
\hline & \multicolumn{7}{|c|}{ Excluding primary solid biofuels, by ... } \\
\hline & Residences $^{\mathrm{F}}$ & Agriculture $^{\mathrm{F}}$ & Transport $^{\mathrm{F}}$ & Industry $^{\mathrm{F}}$ & Services ${ }^{\mathrm{F}}$ & Other & Total \\
\hline \multicolumn{8}{|l|}{ Panel A: No quadratic } \\
\hline \multirow[t]{2}{*}{ Ln GDP per capita } & $0.59 * * *$ & $0.53^{* *}$ & $0.86^{* * *}$ & $0.97 * * *$ & $1.12^{* * *}$ & $1.00 * * *$ & $0.95^{* * *}$ \\
\hline & $(0.07)$ & $(0.22)$ & $(0.06)$ & $(0.10)$ & $(0.13)$ & $(0.14)$ & $(0.07)$ \\
\hline \multirow[t]{2}{*}{ Ln gasoline price } & $-0.15^{*}$ & $0.57 * * *$ & $-0.22 * * *$ & $-0.31 * *$ & $-0.22 *$ & $-0.29 * *$ & $-0.29 * * *$ \\
\hline & $(0.08)$ & $(0.20)$ & $(0.07)$ & $(0.12)$ & $(0.11)$ & $(0.13)$ & $(0.05)$ \\
\hline \multirow{2}{*}{$\begin{array}{l}\text { Temperature (coldest } \\
\text { month) }\end{array}$} & $-0.04 * * *$ & -0.01 & $-0.01 *$ & -0.02 & $-0.04 * * *$ & -0.01 & $-0.02 * * *$ \\
\hline & $(0.01)$ & $(0.02)$ & $(0.01)$ & $(0.01)$ & $(0.01)$ & $(0.01)$ & $(0.01)$ \\
\hline \multirow{2}{*}{$\begin{array}{l}\text { Temperature (warmest } \\
\text { month) }\end{array}$} & 0.02 & -0.03 & 0.03 & -0.01 & 0.03 & 0.00 & 0.01 \\
\hline & $(0.02)$ & $(0.04)$ & $(0.02)$ & $(0.02)$ & $(0.03)$ & $(0.04)$ & $(0.02)$ \\
\hline \multirow[t]{2}{*}{ Ln precipitation } & 0.12 & -0.11 & $0.16^{*}$ & -0.15 & 0.07 & $-0.30 * *$ & -0.07 \\
\hline & $(0.13)$ & $(0.27)$ & $(0.08)$ & $(0.13)$ & $(0.18)$ & $(0.14)$ & $(0.07)$ \\
\hline \multirow[t]{2}{*}{ Ln Population } & 0.08 & -0.18 & $-0.16^{* * *}$ & 0.02 & 0.04 & 0.12 & -0.04 \\
\hline & $(0.07)$ & $(0.14)$ & $(0.04)$ & $(0.08)$ & $(0.10)$ & $(0.10)$ & $(0.05)$ \\
\hline \multirow[t]{2}{*}{ Ln Land } & -0.03 & $0.29 * * *$ & $0.13^{* * *}$ & 0.06 & -0.08 & -0.06 & 0.03 \\
\hline & $(0.05)$ & $(0.09)$ & $(0.03)$ & $(0.06)$ & (0.09) & $(0.08)$ & $(0.04)$ \\
\hline$R^{2}$ & 0.83 & 0.62 & 0.91 & 0.84 & 0.78 & 0.76 & 0.93 \\
\hline \multicolumn{8}{|c|}{ Panel B: With quadratic (coefficients for controls not shown) } \\
\hline \multirow[t]{2}{*}{ Ln GDP per capita } & -0.18 & 0.77 & $1.19 * *$ & 0.06 & 0.46 & -0.12 & 0.78 \\
\hline & $(0.73)$ & $(3.81)$ & $(0.48)$ & $(0.91)$ & $(1.55)$ & $(1.96)$ & $(0.80)$ \\
\hline \multirow[t]{2}{*}{ 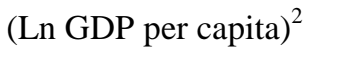 } & 0.04 & -0.01 & -0.02 & 0.05 & 0.04 & 0.06 & 0.01 \\
\hline & $(0.04)$ & $(0.21)$ & $(0.03)$ & $(0.05)$ & $(0.09)$ & $(0.10)$ & $(0.04)$ \\
\hline$R^{2}$ & 0.83 & 0.62 & 0.91 & 0.84 & 0.78 & 0.76 & 0.93 \\
\hline Energy-GDP & Positive & Positive & Positive & Positive & Positive & Positive & Positive \\
\hline \multirow{2}{*}{\multicolumn{8}{|c|}{ Elasticity evaluated at $x^{\text {th }}$ percentile of GDP per capita... }} \\
\hline & & & & & & & \\
\hline $25^{\text {th }}$ & $0.54 * * *$ & 0.54 & $0.88 * * *$ & $0.92 * * *$ & $1.08 * * *$ & $0.91 * * *$ & $0.94 * * *$ \\
\hline $50^{\text {th }}$ & $0.63 * * *$ & $0.52 * * *$ & $0.84 * * *$ & $1.02 * * *$ & $1.16^{* * *}$ & $1.03^{* * *}$ & $0.96 * * *$ \\
\hline $75^{\text {th }}$ & $0.70 * * *$ & 0.49 & $0.81^{* * *}$ & $1.11^{* * *}$ & $1.22 * * *$ & $1.14^{* * *}$ & $0.97 * * *$ \\
\hline \multicolumn{8}{|c|}{ Panel C: Dependent variable: Ln Per capita use of primary solid biofuel energy (coefficients on controls not shown) } \\
\hline Ln GDP per capita & $\begin{array}{l}-0.67 * * * \\
(0.22)\end{array}$ & $\begin{array}{l}-0.13 \\
(0.60)\end{array}$ & n.a. & $\begin{array}{l}0.59 * * \\
(0.26)\end{array}$ & $\begin{array}{l}-0.42 \\
(0.37)\end{array}$ & $\begin{array}{l}0.56^{* * *} \\
(0.19)\end{array}$ & $\begin{array}{l}0.06 \\
(0.22)\end{array}$ \\
\hline $\begin{array}{l}\text { Controls and region } \\
\text { dummies }\end{array}$ & Yes & Yes & Yes & Yes & Yes & Yes & Yes \\
\hline Observations (max) & 132 & 114 & 132 & 132 & 130 & 121 & 132 \\
\hline
\end{tabular}

Notes: ${ }^{* *},{ }^{* *}$, and * indicate statistical significance at 1, 5, and 10\%. Robust standard errors are in parentheses. Coefficients for the transition economy dummy and region dummies not shown. The samples in columns 2, 5, and 6 are reduced due to instances of $\ln (0)$ or, in the case of column $6, \ln (<0)$. Panel B: The GDP per capita percentiles are for the full sample. The energy-GDP relationship is never classed as $U$ or inverse $U$ because the quadratic terms are not significant. Panel C: Estimation samples are reduced due to instances of $\ln (0)$. It is not possible to estimate an elasticity for transport for this reason.

Panel C of Table 3 presents GDP elasticities for primary solid biofuels alone. ${ }^{9}$ We obtain a negative elasticity for residences, statistically significant at the $1 \%$ level. When looking across countries, higher GDP per capita is thus associated with less per capita use of primary

\footnotetext{
${ }^{9}$ The reader is reminded of measurement issues for the biofuels data. This specification uses only the cross-sectional variation.
} 
solid biofuels by residences. ${ }^{10}$ Positive elasticities are obtained for industry and the "other" category, the latter reflecting increased use of primary solid biofuels at higher income levels for transformation processes such as electricity generation and the making of liquid biofuels. The GDP elasticity for aggregate primary solid biofuel use is 0.06 , insignificantly different from zero. At a macro level, primary solid biofuel use is thus very GDP inelastic.

The results together suggest that the role of primary solid biofuels - particularly by residences - is the key to understanding why the energy-GDP elasticity is on average higher at higher GDP per capita. Primary solid biofuels dominate the energy mixes of low-income economies such as the Democratic Republic of the Congo, but residential use of these fuels tends to fall if these economies experience economic growth. Use of commercial fuels tends to increase, and commercial fuels offer energy efficiency improvements over traditional fuels. As a result, the aggregate energy-GDP elasticity is on average low at low income levels. Once commercial fuels are dominant, the energy-GDP elasticity becomes higher.

Table 4 presents results for electricity use. Electricity is the highest-quality energy form for many purposes. As expected, the electricity-GDP elasticities are generally larger than the energy-GDP elasticities presented in Table 1, suggesting that economic growth induces a switch toward electricity. This is particularly so for residences (electricity-GDP elasticity of 0.78) and transport (1.35). The aggregate electricity-GDP is 0.88 (Panel A). This elasticity appears to be relatively stable across the GDP per capita distribution, as evidenced by the insignificant estimates for the quadratic term in Panel B of Table 4.

In sum, the energy-GDP elasticity for residences varies substantially by fuel. The elasticity for residential use of primary solid biofuels is negative, consistent with this fuel being an inferior good at the residential level. Excluding primary solid fuels, or restricting energy use to electricity only, the residential GDP elasticity is positive. Once the negative and positive effects are netted out, the energy-GDP elasticity for residences is positive, but rather small (0.33). Agriculture has a mid-range energy-GDP elasticity point estimate of 0.50 . Transport has a high energy-GDP elasticity, particularly for electricity. Industry and services have relatively high energy-GDP elasticities. GDP elasticities are generally higher for the use of commercial energy sources such as electricity than the use of traditional sources such as primary solid biofuels.

\footnotetext{
${ }^{10}$ Female labor force participation is among other variables associated with reductions in residential use of biofuels; see Burke and Dundas (2015).
} 


\section{Table 4}

Levels estimates for electricity use, 2010.

Dependent variable: Ln per capita electricity use (final) by ...

\begin{tabular}{|c|c|c|c|c|c|c|c|}
\hline & $\begin{array}{l}(1) \\
\text { Residences }\end{array}$ & $\begin{array}{l}\text { (2) } \\
\text { Agriculture }\end{array}$ & $\begin{array}{l}\text { (3) } \\
\text { Transport }\end{array}$ & $\begin{array}{l}\text { (4) } \\
\text { Industry }\end{array}$ & $\begin{array}{l}\text { (5) } \\
\text { Services }\end{array}$ & $\begin{array}{l}\text { (6) } \\
\text { Other }\end{array}$ & $\begin{array}{l}(7) \\
\text { Total }\end{array}$ \\
\hline \multicolumn{8}{|c|}{ Panel A: No quadratic } \\
\hline Ln GDP per capita & $\begin{array}{l}0.78^{* * *} \\
(0.08)\end{array}$ & $\begin{array}{l}0.50^{* *} \\
(0.22)\end{array}$ & $\begin{array}{l}1.35^{* * *} \\
(0.22)\end{array}$ & $\begin{array}{l}0.88^{* * *} \\
(0.13)\end{array}$ & $\begin{array}{l}1.18^{* * *} \\
(0.11)\end{array}$ & $\begin{array}{l}1.18 \\
(0.82)\end{array}$ & $\begin{array}{l}0.88^{* * *} \\
(0.09)\end{array}$ \\
\hline Ln gasoline price & $\begin{array}{l}-0.06 \\
(0.09)\end{array}$ & $\begin{array}{l}0.04 \\
(0.17)\end{array}$ & $\begin{array}{l}0.08 \\
(0.23)\end{array}$ & $\begin{array}{l}-0.03 \\
(0.19)\end{array}$ & $\begin{array}{l}-0.03 \\
(0.10)\end{array}$ & $\begin{array}{l}0.05 \\
(1.68)\end{array}$ & $\begin{array}{l}-0.05 \\
(0.10)\end{array}$ \\
\hline $\begin{array}{l}\text { Temperature } \\
\text { (coldest month) }\end{array}$ & $\begin{array}{l}-0.01 \\
(0.01)\end{array}$ & $\begin{array}{l}-0.00 \\
(0.03)\end{array}$ & $\begin{array}{l}-0.07 * * \\
(0.03)\end{array}$ & $\begin{array}{l}-0.04 * * \\
(0.02)\end{array}$ & $\begin{array}{l}-0.01 \\
(0.01)\end{array}$ & $\begin{array}{l}-0.01 \\
(0.12)\end{array}$ & $\begin{array}{l}-0.01 \\
(0.01)\end{array}$ \\
\hline $\begin{array}{l}\text { Temperature } \\
\text { (warmest month) }\end{array}$ & $\begin{array}{l}-0.00 \\
(0.02)\end{array}$ & $\begin{array}{l}-0.03 \\
(0.07)\end{array}$ & $\begin{array}{l}0.04 \\
(0.05)\end{array}$ & $\begin{array}{l}-0.04 \\
(0.03)\end{array}$ & $\begin{array}{l}0.02 \\
(0.02)\end{array}$ & $\begin{array}{l}-0.16 \\
(0.26)\end{array}$ & $\begin{array}{l}-0.02 \\
(0.02)\end{array}$ \\
\hline Ln precipitation & $\begin{array}{l}0.01 \\
(0.10)\end{array}$ & $\begin{array}{l}-0.24 \\
(0.33)\end{array}$ & $\begin{array}{l}0.07 \\
(0.41)\end{array}$ & $\begin{array}{l}-0.06 \\
(0.18)\end{array}$ & $\begin{array}{l}0.08 \\
(0.11)\end{array}$ & $\begin{array}{l}-2.31 \\
(1.80)\end{array}$ & $\begin{array}{l}-0.08 \\
(0.11)\end{array}$ \\
\hline Ln Population & $\begin{array}{l}-0.10^{* *} \\
(0.05)\end{array}$ & $\begin{array}{l}-0.10 \\
(0.14)\end{array}$ & $\begin{array}{l}0.19 \\
(0.15)\end{array}$ & $\begin{array}{l}0.03 \\
(0.11)\end{array}$ & $\begin{array}{l}-0.10 \\
(0.07)\end{array}$ & $\begin{array}{l}0.45 \\
(0.69)\end{array}$ & $\begin{array}{l}-0.06 \\
(0.06)\end{array}$ \\
\hline Ln Land & $\begin{array}{l}0.02 \\
(0.05)\end{array}$ & $\begin{array}{l}0.17 \\
(0.11)\end{array}$ & $\begin{array}{l}-0.04 \\
(0.18)\end{array}$ & $\begin{array}{l}-0.02 \\
(0.10)\end{array}$ & $\begin{array}{l}0.03 \\
(0.05)\end{array}$ & $\begin{array}{l}-0.64 \\
(0.55)\end{array}$ & $\begin{array}{l}0.00 \\
(0.05)\end{array}$ \\
\hline$R^{2}$ & 0.87 & 0.49 & 0.70 & 0.74 & 0.89 & 0.24 & 0.88 \\
\hline \multicolumn{8}{|c|}{ Panel B: With quadratic (coefficients for controls not shown) } \\
\hline Ln GDP per capita & $\begin{array}{l}0.17 \\
(0.83)\end{array}$ & $\begin{array}{l}1.08 \\
(3.06)\end{array}$ & $\begin{array}{l}-2.54 \\
(3.43)\end{array}$ & $\begin{array}{l}0.06 \\
(1.08)\end{array}$ & $\begin{array}{l}1.36 \\
(1.20)\end{array}$ & $\begin{array}{l}6.66 \\
(8.78)\end{array}$ & $\begin{array}{l}0.18 \\
(0.89)\end{array}$ \\
\hline (Ln GDP per & 0.04 & -0.03 & 0.21 & 0.05 & -0.01 & -0.31 & 0.04 \\
\hline capita $)^{2}$ & $(0.05)$ & $(0.17)$ & $(0.19)$ & $(0.06)$ & $(0.07)$ & $(0.49)$ & $(0.05)$ \\
\hline$R^{2}$ & 0.88 & 0.49 & 0.71 & 0.74 & 0.89 & 0.25 & 0.88 \\
\hline $\begin{array}{l}\text { Electricity-GDP } \\
\text { relationship is: }\end{array}$ & Positive & Positive & Positive & Positive & Positive & Insignificant & Positive \\
\hline \multicolumn{8}{|c|}{ Elasticity evaluated at $x^{\text {th }}$ percentile of GDP per capita... } \\
\hline $25^{\text {th }}$ & $0.74^{* * *}$ & 0.53 & $0.96 * *$ & $0.84 * * *$ & $1.19 * * *$ & 1.55 & $0.84^{* * *}$ \\
\hline $50^{\text {th }}$ & $0.81 * * *$ & $0.47 * *$ & $1.37 * * *$ & $0.93 * * *$ & $1.17 * * *$ & 0.95 & $0.92 * * *$ \\
\hline $75^{\text {th }}$ & $0.87 * * *$ & 0.41 & $1.75 * * *$ & $1.01 * * *$ & $1.15^{* * *}$ & 0.40 & $0.99 * * *$ \\
\hline $\begin{array}{l}\text { Controls and } \\
\text { region dummies }\end{array}$ & Yes & Yes & Yes & Yes & Yes & Yes & Yes \\
\hline Observations & 131 & 101 & 74 & 131 & 125 & 97 & 132 \\
\hline \multicolumn{8}{|c|}{$\begin{array}{l}\text { Notes: } * * *, * * \text {, and * indicate statistical significance at } 1,5 \text {, and } 10 \% \text {. Robust standard errors are in parentheses. } \\
\text { Coefficients for the transition economy dummy and region dummies not shown. Samples are reduced below } 132 \\
\text { due to instances of } \ln (0) \text {. The "other" category includes only non-specified final electricity use. The GDP per } \\
\text { capita percentiles are for the full sample. The electricity-GDP relationship is never classed as U or inverse U } \\
\text { because the quadratic terms are not significant. }\end{array}$} \\
\hline
\end{tabular}

\subsection{Growth rates results}

Estimates of our 10-year growth rates model are in Table 5. The first row provides the energy-GDP elasticities for countries with mean $t-10 \log$ GDP per capita. As expected, these are generally smaller than the cross-sectional estimates. The mean elasticity is particularly low for residences: 0.05 , which is not significantly different from zero. The mean 10-year energy-GDP elasticity for transport is 0.66 ; for industry is 0.73 ; and for services is 0.56 . The 10 -year energy-GDP elasticity for agriculture is similar to the levels regression (0.52). The 10 -year GDP elasticity for all energy use is 0.48 , two-thirds the size of the estimate in Table 1. This is similar to the energy-GDP elasticity reported by Csereklyei and Stern (2015) in their base 39-year growth rates model with spatial filtering (Model 1 of their Table 2) and to the two-year response reported by Burke et al. (2015). 
Table 5

Panel estimates in 10-year growth rates, 1960-2010.

\begin{tabular}{|c|c|c|c|c|c|c|c|}
\hline $\begin{array}{l}\text { 10-year average annual growth rate of per } \\
\text { capita... }\end{array}$ & $\begin{array}{l}1) \\
\text { energy use by ... } \\
\text { Residences }^{\mathrm{F}}\end{array}$ & $\begin{array}{l}\text { (2) } \\
\text { Agriculture }^{\mathrm{F}}\end{array}$ & $\begin{array}{l}\text { (3) } \\
\text { Transport }^{\mathrm{F}}\end{array}$ & $\begin{array}{l}\text { (4) } \\
\text { Industry }^{\mathrm{F}}\end{array}$ & $\begin{array}{l}\text { (5) } \\
\text { Services }^{F}\end{array}$ & Other & (7) \\
\hline GDP per capita growth rate ${ }_{10 \text {-year }}$ & $\begin{array}{l}0.05 \\
(0.11)\end{array}$ & $\begin{array}{l}0.52^{*} \\
(0.28)\end{array}$ & $\begin{array}{l}0.66^{* * *} \\
(0.06)\end{array}$ & $\begin{array}{l}0.73^{* * *} \\
(0.19)\end{array}$ & $\begin{array}{l}0.56 * * * \\
(0.19)\end{array}$ & $\begin{array}{l}0.59 * * * \\
(0.09)\end{array}$ & $\begin{array}{l}0.48^{* * *} \\
(0.05)\end{array}$ \\
\hline $\begin{array}{l}\text { GDP per capita growth rate } \\
\text { per capita }_{t-10} \text {; sample demeaned }\end{array}$ & $\begin{array}{l}0.05 \\
(0.06)\end{array}$ & $\begin{array}{l}0.25 \\
(0.22)\end{array}$ & $\begin{array}{l}0.05 \\
(0.04)\end{array}$ & $\begin{array}{l}0.25^{* *} \\
(0.11)\end{array}$ & $\begin{array}{l}0.41^{* * *} \\
(0.14)\end{array}$ & $\begin{array}{l}-0.04 \\
(0.09)\end{array}$ & $\begin{array}{l}0.13^{* * * *} \\
(0.03)\end{array}$ \\
\hline Ln GDP per capita $a_{t-10}$ & $\begin{array}{l}0.008^{* *} \\
(0.003)\end{array}$ & $\begin{array}{l}0.006 \\
(0.011)\end{array}$ & $\begin{array}{l}0.029 * * * \\
(0.005)\end{array}$ & $\begin{array}{l}0.012^{* * *} \\
(0.004)\end{array}$ & $\begin{array}{l}0.033^{* * *} \\
(0.008)\end{array}$ & $\begin{array}{l}0.032^{* * *} \\
(0.005)\end{array}$ & $\begin{array}{l}0.016^{* * *} \\
(0.004)\end{array}$ \\
\hline $\begin{array}{l}\text { Ln Energy or electricity use per capita in that } \\
\text { sector }_{t-10}\end{array}$ & $\begin{array}{l}-0.033^{* * *} \\
(0.008)\end{array}$ & $\begin{array}{l}-0.025^{* * *} \\
(0.009)\end{array}$ & $\begin{array}{l}-0.035^{* * *} \\
(0.004)\end{array}$ & $\begin{array}{l}-0.025^{* * *} \\
(0.005)\end{array}$ & $\begin{array}{l}-0.040^{* * *} \\
(0.004)\end{array}$ & $\begin{array}{l}-0.028^{* * *} \\
(0.003)\end{array}$ & $\begin{array}{l}-0.023^{* * *} \\
(0.004)\end{array}$ \\
\hline 1981 dummy & $\begin{array}{l}-0.027 * * \\
(0.011)\end{array}$ & & $\begin{array}{l}-0.011^{*} \\
(0.006)\end{array}$ & $\begin{array}{l}-0.026^{* * *} \\
(0.007)\end{array}$ & $\begin{array}{l}-0.007 \\
(0.018)\end{array}$ & $\begin{array}{l}-0.032^{* * *} \\
(0.008)\end{array}$ & $\begin{array}{l}-0.021^{* * *} \\
(0.005)\end{array}$ \\
\hline 1990 dummy & $\begin{array}{l}-0.030^{* * *} \\
(0.010)\end{array}$ & & $\begin{array}{l}-0.011^{*} \\
(0.006)\end{array}$ & $\begin{array}{l}-0.027^{* *} \\
(0.011)\end{array}$ & $\begin{array}{l}0.002 \\
(0.018)\end{array}$ & $\begin{array}{l}-0.034^{* * * *} \\
(0.008)\end{array}$ & $\begin{array}{l}-0.025^{* * *} \\
(0.005)\end{array}$ \\
\hline 2000 dummy & $\begin{array}{l}-0.030^{* * *} \\
(0.011)\end{array}$ & & $\begin{array}{l}-0.007 \\
(0.005)\end{array}$ & $\begin{array}{l}-0.030^{* * *} \\
(0.010)\end{array}$ & $\begin{array}{l}0.004 \\
(0.017)\end{array}$ & $\begin{array}{l}-0.043^{* * *} \\
(0.009)\end{array}$ & $\begin{array}{l}-0.029 * * * \\
(0.005)\end{array}$ \\
\hline 2010 dummy & $\begin{array}{l}-0.032 * * * \\
(0.010)\end{array}$ & $\begin{array}{l}0.000 \\
(0.012)\end{array}$ & $\begin{array}{l}-0.004 \\
(0.006)\end{array}$ & $\begin{array}{l}-0.035^{* * *} \\
(0.008)\end{array}$ & $\begin{array}{l}-0.004 \\
(0.018)\end{array}$ & $\begin{array}{l}-0.046^{* * *} \\
(0.008)\end{array}$ & $\begin{array}{l}-0.029 * * * \\
(0.005)\end{array}$ \\
\hline Controls and region dummies & Yes & Yes & Yes & Yes & Yes & Yes & Yes \\
\hline$R^{2}$ & 0.46 & 0.19 & 0.46 & 0.37 & 0.47 & 0.42 & 0.61 \\
\hline \multicolumn{8}{|c|}{10 -year elasticity evaluated at $x^{\text {th }}$ percentile of GDP per capita $t_{t-10} \ldots$} \\
\hline $25^{\text {th }}$ & 0.00 & 0.28 & $0.62 * * *$ & $0.50 * * *$ & 0.19 & $0.63^{* * *}$ & $0.36 * * *$ \\
\hline $75^{\text {th }}$ & 0.11 & $0.78 * *$ & $0.71^{* * *}$ & $0.98^{* * *}$ & $0.98 * * *$ & $0.55^{* * *}$ & $0.62 * * *$ \\
\hline Long-run elasticity & $0.25 * *$ & 0.25 & $0.84 * * *$ & $0.48 * * *$ & $0.83^{* * *}$ & $1.15^{* * *}$ & $0.71^{* * *}$ \\
\hline Countries & 131 & 109 & 131 & 131 & 126 & 131 & 131 \\
\hline Observations & 463 & 195 & 463 & 459 & 419 & 463 & 463 \\
\hline
\end{tabular}

Observations

$195-463$

459

419

463

463

, and * indicate statistical significance at 1,5 , and 10\%. Robust standard efrors, clustered by countiry, are in parenthe

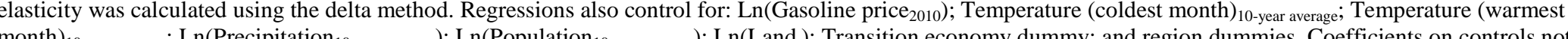
reported. The decade-dummy base year is 1970 . The sample demeaning and percentiles are for the 463-observation sample. Some samples are reduced due to instances of $\ln (0)$. The estimates for agriculture are restricted to the two 10-year periods ending in 2000 and 2010. Growth rates are annual averages, calculated using differenced logs divided by 10; 0.01 approximately equals $1 \%$ average annual growth. The long-run elasticity is evaluated for a future GDP per capita growth rate of zero. 
The second row of coefficients in Table 5 shows how the energy-GDP elasticity varies with the level of $t-10 \log$ GDP per capita. The significant positive coefficient in column 7 again suggests that the aggregate energy-GDP elasticity is higher at higher GDP per capita. EnergyGDP elasticities evaluated at the $25^{\text {th }}$ and $75^{\text {th }}$ percentiles of $t-10 \log$ GDP per capita are shown at the base of the table, with the point elasticities equalling 0.36 at the $25^{\text {th }}$ percentile of $t-10$ GDP per capita, and 0.62 at the $75^{\text {th }}$ percentile. The estimates thus provide no evidence of a reduction in the conditional energy-GDP elasticity at higher GDP per capita as might have been expected if there was a delinking of energy use from economic growth. The second-row coefficients are also positive and statistically significant for industry and services.

The long-run energy-GDP elasticities from our growth rates estimates are also in the base of Table 5. These measure the cumulative effect of a current shock to GDP per capita, assuming that the GDP per capita growth rate in future periods is zero. The general story is similar to Table 1, with the long-run energy-GDP elasticity equalling around 0.7. At the sectoral level, the elasticity for residences is 0.25 and for transport and services around 0.8 , again similar to Table 1. The main difference is that the long-run elasticity for industry is here only 0.48 . An imprecise estimate of the long-run energy-GDP elasticity is obtained for agriculture. We only use two decades of data for this sector.

Results for the controls in Table 5 also contain valuable information. We find strong beta convergence in each sector: conditional on the covariates, convergence in per capita energy use occurs at $2.3 \%$ per annum on average, strikingly similar to the conditional GDP per capita convergence rate reported by Barro (2015). The estimates also reveal that higher $t-10$ GDP per capita is associated with faster subsequent growth in energy use, holding the other variables - including the decade's GDP per capita growth rate and $t-10$ energy use - fixed. This makes sense: it is natural to expect that countries with lower $t-10$ energy intensity will experience smaller reductions in energy intensity over time. ${ }^{11}$ The coefficients for the decade dummies are generally negative, suggestive of downward pressure on per capita energy use growth relative to the 1960 s.

Table 6 presents 10-year growth rates estimates for (a) energy use excluding primary solid biofuels, and (b) electricity use. We consolidate to six categories. We again obtain larger mean 10-year energy-GDP elasticities for residences (0.18) and in total (0.62) when primary solid biofuels are excluded. The estimate for residences differs from zero at the $10 \%$ level. There is again no evidence that the total 10-year energy-GDP elasticity is higher for countries with higher $t-10$ GDP per capita once primary solid biofuels are excluded (see the secondrow coefficients). The 10-year electricity-GDP elasticity (0.61) exceeds the 10-year energyGDP elasticity (0.48; see Table 5), reflecting electrification of the energy mix as economies

\footnotetext{
${ }^{11}$ An alternative parameterization is to include $t-10 \log$ energy intensity instead of $t-10$ log energy use per capita, with $\log$ energy intensity defined as $\ln E-\ln Y$. This will produce the same coefficient $\left(-0.023^{* * *}\right.$ in column 7 of Table 5). The coefficient for $\ln Y$ becomes $-0.007^{* *}$, the sum of $\theta$ and $\kappa$ in Eq. (5) (i.e. 0.016 - 0.023). Csereklyei and Stern (2015) refer to a negative coefficient for $\ln Y$ in this specification as evidence of a "weak decoupling" that is separable from an energy intensity effect.
} 
grow. Conditional convergence and generally negative time effects continue to be observed. The long-run energy-GDP elasticities are generally similar to the levels estimates in Tables 3 and 4.

\section{Table 6}

Panel estimates in 10-year growth rates for energy excluding primary solid biofuels and for electricity, 1960-2010.

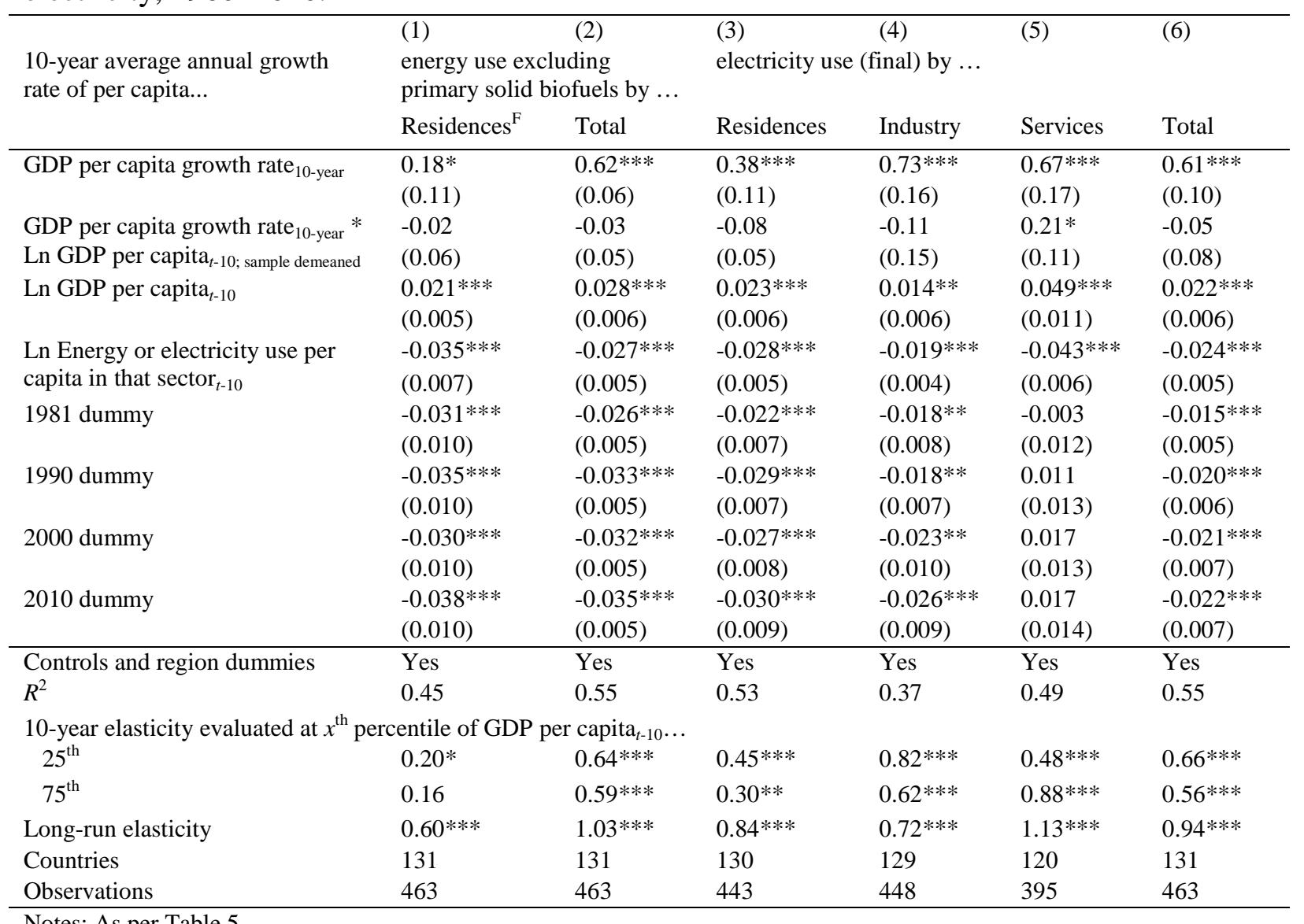

\subsection{Heterogeneity}

We now turn to tests of group-based heterogeneity in the energy-income elasticity. We use our 10-year growth rates model, restricting the sample to countries with a year-2010 population exceeding one million people. We do so because heterogeneity analysis hones in on effects for sub-groups, and we do not want the results to be overly influenced by small countries. The restriction excludes five small countries: Brunei Darussalam, Iceland, Luxembourg, Malta, and Qatar. We remove the growth-level interaction (i.e. impose $\eta=0$ ), instead adding interactions between GDP per capita growth and group dummies. Our estimates control for group level effects and the controls from Eq. (5). We do not present the coefficients for the controls. We also do not consider potential group-by-group heterogeneity in the effects of other variables.

Panel A of Table 7 presents the mean 10-year energy-GDP elasticities without any interactions. They are similar to the 10-year energy-GDP elasticities from Tables 5 and 6. 
Table 7

Heterogeneity analysis using 10-year growth rates, 1960-2010: by region. Energy-GDP elasticity Energy-GDP elasticity, Electricity-GDP elasticity excluding primary

solid biofuels

Residences $^{\mathrm{F}} \quad$ Transport $^{\mathrm{F}} \quad$ Industry $^{\mathrm{F}}$ Services ${ }^{\mathrm{F}}$ Other Total $^{\text {Residences }}{ }^{\mathrm{F}}$ Total Residences Industry Services Total

\begin{tabular}{|c|c|c|c|c|c|c|c|c|c|c|c|c|}
\hline A. Overall average & 0.04 & $0.64 * * *$ & $0.66 * * *$ & $0.45^{* *}$ & $0.63 * * *$ & $0.43^{* * *}$ & $0.22 *$ & $0.64 * * *$ & $0.44^{* * *}$ & $0.77 * * *$ & $0.63 * * *$ & $0.67 * * *$ \\
\hline \multicolumn{13}{|c|}{ B. By region $($ bold italic $=$ differs from East Asia and Pacific at $5 \%$ significance) } \\
\hline East Asia and Pacific & 0.25 & $0.87 * * *$ & $0.86^{* * *}$ & $1.08 * * *$ & $0.81^{* * *}$ & $0.75^{* * *}$ & 0.33 & $0.89 * * *$ & $0.81^{* * *}$ & $1.31 * * *$ & $0.64^{* *}$ & $1.11^{* * *}$ \\
\hline Europe \& Central Asia & -0.18 & $0.51 * * *$ & 0.37 & 0.33 & $0.54 * * *$ & $0.40 * * *$ & -0.08 & $0.46^{* * *}$ & 0.00 & $0.55^{* *}$ & $0.55^{*}$ & $0.35^{* * *}$ \\
\hline Latin America \& Caribbean & $0.31^{* * *}$ & $0.71^{* * *}$ & $0.82 * * *$ & $0.78 * *$ & $0.89 * * *$ & $0.59 * * *$ & $0.57^{* * *}$ & $0.69 * * *$ & $0.54^{* * *}$ & $1.06^{* * *}$ & $0.75^{* *}$ & $0.81^{* * *}$ \\
\hline Middle East \& North Africa & 0.35 & $0.50 * * *$ & $1.51^{* *}$ & 0.93 & $0.46^{*}$ & $0.57 * * *$ & 0.49 & $0.61 * * *$ & 0.72 & -0.28 & 1.07 & $0.79 * *$ \\
\hline North America & -0.15 & $1.52 * * *$ & $1.35^{* * *}$ & $2.52 * *$ & $0.74 * * *$ & $0.83 * * *$ & 0.26 & $0.87 * * *$ & 0.47 & $1.47 * * *$ & $2.61 * * *$ & $0.90^{* * *}$ \\
\hline South Asia & 0.34 & $1.03^{* * *}$ & $0.82 * *$ & -0.28 & 0.43 & $0.47 * * *$ & $0.67 * * *$ & $0.40 *$ & $0.89 * *$ & $0.70^{*}$ & 0.24 & $0.76 * *$ \\
\hline Sub-Saharan Africa & -0.11 & $0.72 * * *$ & 0.36 & -0.11 & $0.64 * *$ & $0.16^{* *}$ & 0.17 & $0.78 * * *$ & $0.66^{* * *}$ & $1.06 * * *$ & $0.53^{* *}$ & $0.73^{* * *}$ \\
\hline
\end{tabular}

Notes: ***, **, and * indicate statistically different from zero at the 1, 5, and 10\% levels. These are 10-year elasticities from estimates of the type in Tables 5-6, excluding the interaction between GDP per capita growth and $t-10 \log$ GDP per capita. Panel B instead uses interactions between GDP per capita growth and region. Each cell in Panel B shows the implied

elasticity for that region. Regions follow the World Bank definition. Countries with a year-2010 population of less than 1,000,000 are excluded. Maximum sample: 443 observations from 126 countries. Coefficients on controls not shown. Agriculture is excluded given the small size of the sector and the relative imprecision of our energy-GDP elasticities for this sector (see Fig. 3) 
Panel B of Table 7 presents the mean 10-year energy-GDP elasticities by region. These are calculated by adding the coefficient on GDP per capita growth and the coefficient on the relevant growth-country group interaction. The energy-GDP elasticity for residences is only significantly different from zero in Latin America and the Caribbean, with a point estimate of 0.31. The elasticity for transport is significant in all regions, highest in North America, and lowest in the Middle East and North Africa. For industry the lowest elasticities are for (a) Sub-Saharan Africa and (b) Europe and Central Asia, although these are not significantly different from the elasticity for East Asia and the Pacific. The services elasticity for SubSaharan Africa is not significantly different from zero and is substantially lower than that for East Asia and the Pacific (1.08). The lowest 10-year energy-GDP elasticity for energy use across all sectors is Sub-Saharan Africa's (0.16). The highest is North America's (0.83). Our earlier results suggest that Sub-Saharan Africa's low energy-GDP elasticity is due to high reliance on traditional fuels.

Turning to electricity, we find that East Asia and the Pacific has had the highest electricity intensity of GDP growth in point estimate terms. The smallest 10-year electricity-GDP elasticity is for Europe and Central Asia (0.35), well below the overall mean of 0.67 but still significantly different from zero. Europe and Central Asia's use of electricity by residences is particularly GDP inelastic (point estimate of 0.00). While some European countries such as Germany and Sweden have experienced a maturation of per capita residential electricity use during our sample period, this is not the case in every country. The very low electricity-GDP elasticity indicates, however, that increases/decreases in residential electricity use in the region have not been strongly correlated with economic growth on a decadal basis, after the effects of the control variables have been considered.

Panel A of Table 8 suggests that energy-GDP elasticities are similar for fossil-fuel rich economies and others. Panel B then presents elasticities for the World Bank's high income group and for other countries. When primary solid biofuels are included, the 10-year energyGDP elasticity is higher for high-income countries (0.70) than others $(0.36)$, with the difference significant at the $1 \%$ level. This is consistent with our finding that the energy-GDP elasticity increases along the GDP per capita spectrum. This phenomenon reduces when energy excludes primary solid biofuels, or is restricted to only electricity (the later columns). 
Table 8

Heterogeneity analysis using 10-year growth rates, 1960-2010: by country group.

\begin{tabular}{|c|c|c|c|c|c|c|c|c|c|c|c|c|c|}
\hline & \multirow[t]{2}{*}{$\begin{array}{l}\text { Number } \\
\text { of } \\
\text { countries }\end{array}$} & \multicolumn{6}{|c|}{ Energy-GDP elasticity } & \multicolumn{2}{|c|}{$\begin{array}{l}\text { Energy-GDP } \\
\text { elasticity, excluding } \\
\text { primary solid biofuels }\end{array}$} & \multicolumn{4}{|c|}{ Electricity-GDP elasticity } \\
\hline & & Residences $^{\mathrm{F}}$ & Transport ${ }^{\mathrm{F}}$ & Industry ${ }^{\mathrm{F}}$ & Services $^{\mathrm{F}}$ & Other & Total & Residences ${ }^{\mathrm{F}}$ & Total & Residences & Industry & Services & Total \\
\hline \multicolumn{14}{|c|}{ A. Fossil fuel rich vs others (coefficients for the two groups never different at the $5 \%$ significance level) } \\
\hline $\begin{array}{l}\text { Non-fossil fuel } \\
\text { rich }\end{array}$ & 93 & 0.03 & $0.67 * * *$ & $0.71 * * *$ & 0.31 & $0.62 * * *$ & $0.42 * * *$ & $0.20 * *$ & $0.65 * * *$ & $0.42 * * *$ & $0.73^{* * *}$ & $0.51 * *$ & $0.66^{* * *}$ \\
\hline Fossil fuel rich & 33 & 0.06 & $0.60 * * *$ & $0.58^{* * *}$ & $0.69 *$ & $0.61 * * *$ & $0.47 * * *$ & 0.22 & $0.61 * * *$ & $0.54 * *$ & $0.88^{* * *}$ & $0.96 * * *$ & $0.74 * * *$ \\
\hline \multicolumn{14}{|c|}{ B. High income vs others (bold italic = differs from high-income countries at 5\% significance) } \\
\hline High income & 45 & -0.04 & $0.78 * * *$ & $0.82 * * *$ & $0.99 * * *$ & $0.78 * * *$ & $0.70^{* * *}$ & 0.02 & $0.75 * * *$ & $0.50 * *$ & 0.40 & $0.94^{* * *}$ & $0.70^{* * *}$ \\
\hline $\begin{array}{l}\text { Middle \& low } \\
\text { income }\end{array}$ & 81 & 0.04 & $0.61 * * *$ & $0.61^{* *}$ & 0.27 & $0.60 * * *$ & $0.36^{* * *}$ & $0.26 * *$ & $0.62 * * *$ & $0.42 * * *$ & $0.86^{* * *}$ & $0.51 * *$ & $0.66^{* * *}$ \\
\hline \multicolumn{14}{|c|}{ C. OECD23 vs others (bold italic $=$ differs from OECD23 at 5\% significance) } \\
\hline OECD23 & 21 & -0.14 & $0.74 * * *$ & $0.94^{* * *}$ & 0.66 & $0.80 * * *$ & $0.71^{* * *}$ & -0.09 & $0.77 * * *$ & $0.55^{* * *}$ & $1.08 * * *$ & 0.27 & $0.79 * * *$ \\
\hline Non-OECD23 & 105 & 0.05 & $0.64 * * *$ & $0.64 * * *$ & $0.43^{*}$ & $0.62 * * *$ & $0.41 * * *$ & $0.24 * *$ & $0.64 * * *$ & $0.43 * * *$ & $0.74 * * *$ & $0.67 * * *$ & $0.66^{* * *}$ \\
\hline \multicolumn{14}{|c|}{ Restricted to two most recent decades (1990-2000; 2000-2010) } \\
\hline OECD23 & 21 & 0.09 & $0.97 * * *$ & $1.22 * * *$ & $0.47 *$ & $0.96 * * *$ & $0.77 * * *$ & 0.20 & $0.86 * * *$ & $0.36 * *$ & $1.13^{* * *}$ & $0.88 * * *$ & $0.83^{* * *}$ \\
\hline Non-OECD23 & 105 & -0.02 & $0.60 * * *$ & $0.47 * *$ & 0.38 & $0.60 * * *$ & $0.37 * * *$ & 0.10 & $0.62 * * *$ & $0.27 * *$ & $0.74 * * *$ & $0.74 * * *$ & $0.51 * * *$ \\
\hline
\end{tabular}

Notes: $* * *, * *$, and * indicate statistically different from zero at the 1, 5, and 10\% levels. These are 10-year elasticities from estimates of the type in Tables 5-6, excluding the interaction between GDP per capita growth and t-10 log GDP per capita. Interactions between GDP per capita growth and group are instead included. Group is also controlled for separately. Each cell provides the implied elasticity for that group. Fossil fuel rich countries are those with fossil fuel rents never exceeding 15\% of GDP in any year during 1970-2010. High income countries are based on current groupings as defined by the World Bank (2015). OECD23 is the 23 OECD member countries as at the end of 1971. Countries with a year-2010 population of less than 1,000,000 are excluded. Maximum sample: 443 observations from 126 countries. Coefficients on controls not shown.

Agriculture is excluded given the small size of the sector and the relative imprecision of our energy-GDP elasticities for this sector (see Fig. 3). 
Remarkably, the United States’ per capita energy use was lower in 2010 than in 1969. Denmark's was lower than in 1969; and the United Kingdom's lower than in 1965. Spurred along by the oil price rises of the 1970s, these reductions have occurred despite sizeable increases in per capita GDP, with the largest proportional energy use reductions in these three countries occurring in the industry sector. To explore, Panel C presents separate effects for both OECD23 and non-OECD23 countries. We find that it is the OECD23 that has the higher 10 -year energy-GDP elasticity ( 0.71 , versus 0.41 for other countries). This is again consistent with our earlier finding that low-income countries tend to have lower energy-GDP elasticities due to their higher reliance on primary solid biofuels, although we note that some nonOECD23 countries have high incomes. Similar results are obtained if the sample is restricted to the two most recent decades (bottom of Panel C). The reductions in energy use in some OECD23 countries thus appear to be explained by factors other than a lowering of the conditional energy-GDP elasticity. Using different approaches, similar results have been presented by Burke et al. (2015), Csereklyei and Stern (2015), and Csereklyei et al. (2016).

\subsection{Decompositions}

Our final step is to use Eq. (3) to provide a sectoral decomposition of the aggregate energyGDP elasticity. The sectoral shares of the energy-GDP elasticity are not the same as the sectoral shares of energy use because, as we have seen, the responsiveness of sectoral energy use to GDP differs by sector. We focus on the long-run point estimates from levels regressions, evaluated using sample-mean energy mix shares. It would be straightforward to perform a similar decomposition using the sectoral energy weights of any specific country, or using the 10-year elasticities. Decompositions for total energy use, energy use excluding primary solid biofuels, and electricity use are presented in Fig. 5.

Fig. 5 shows that the largest contributor to the total energy-GDP elasticity of 0.74 is the "Other" category, a sector that mostly represents primary energy lost in transformation processes such as electricity generation. This is in large part due to electrification of energy systems as economies expand. The second largest contributor is the transport sector. As seen in Fig. 2, much more energy is consumed by this sector in economies with higher incomes. Industry also contributes about one-fifth of the energy-GDP elasticity. Despite its relatively large size (Fig. 2), the inelasticity of residential energy use to GDP means that the sector makes a quite small contribution to the energy-GDP elasticity. Agriculture's contribution is small due to the small energy use of the sector and the moderate GDP elasticity of its energy use. The services sector accounts for almost one-tenth of the mean energy-GDP elasticity.

The energy-GDP elasticity is larger once primary solid biofuels are excluded, as shown by the second bar in Fig. 5. The contribution of the transport sector increases substantially because the sector receives a larger weighting now that we are excluding primary solid biofuels. Residences and industry account for most of the remainder of the increase. 


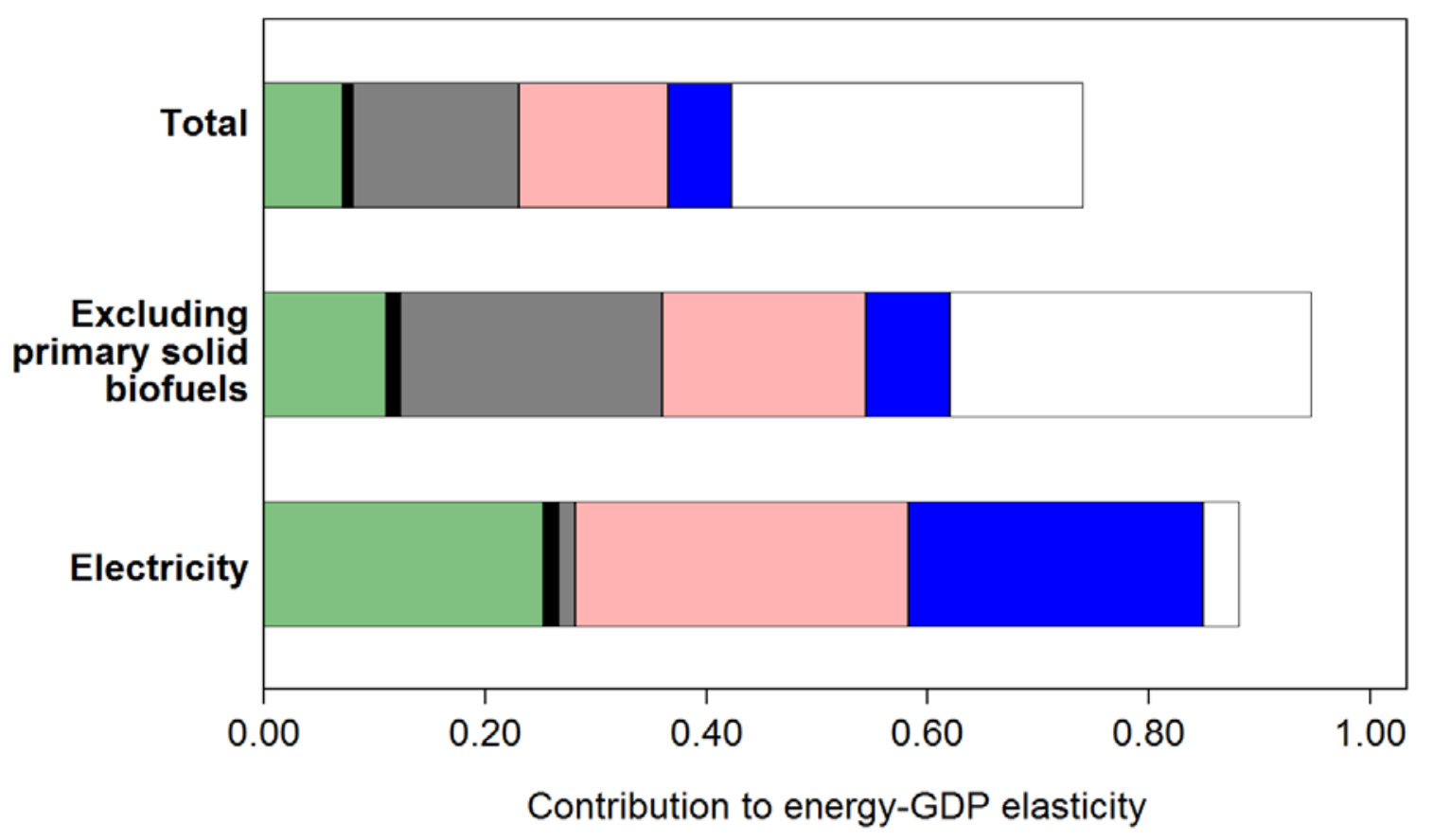

\begin{tabular}{|c|c|c|}
\hline & . & Tra \\
\hline Indust & Services $^{F}$ & Other \\
\hline
\end{tabular}

Fig. 5. Decomposition of mean conditional GDP elasticities for (a) all energy use, (b) energy use excluding primary solid biofuels, and (c) electricity use. The decomposition employs Eq. (3) and the estimates from Tables 1, 3, and 4. Year-2010 simple-average energy-mix weights are used. Minor rescalings were performed. "Other" has a different meaning for the electricity regressions, accounting for only other categories of final use. See Appendix A1 for full definitions.

The sectoral contributions to the electricity-GDP elasticity (third bar in Fig. 5) are rather different to the sectoral contributions to the energy-GDP elasticity. The principal reason is that the electricity data cover only use of final electricity. They do not include transformation losses. The "other" category thus has a different interpretation, covering only other final enduses of electricity. The contribution of residences to the electricity-GDP elasticity is much larger than it was for the energy-GDP elasticity, for two reasons: (1) residential electricity use has a higher GDP elasticity than residential energy use; and (2) residences account for a larger share of final electricity use than of national primary energy use. The contributions of industry and services to the electricity-GDP elasticity are also larger. The contribution of transport is smaller, as this sector remains largely dependent on oil.

\section{Conclusion}

This paper has used data for 132 countries over 51 years to estimate sectoral energy-GDP elasticities. We applied these elasticities to perform a simple decomposition of the aggregate energy-GDP elasticity. The results indicate that residential energy use is very inelastic to national GDP due to the high reliance of many developing economies on traditional fuels. Once primary solid biofuels are excluded, residential energy use is more responsive to GDP, 
with a long-run elasticity of 0.59 . Residential use of electricity has an even higher GDP elasticity (0.78). Economic growth thus induces residential fuel switching toward higherquality energy types. Energy use by agriculture is relatively small and has a below-average GDP elasticity in point estimate terms (0.50). The transport, industry, and services sectors have larger energy-GDP elasticities. The aggregate energy-GDP elasticity tends to be higher for higher-income countries, a key reason being that these economies are mostly reliant on commercial rather than traditional energy sources. The long-run energy-GDP elasticity is less than unity, indicating that economic growth induces reductions in the energy intensity of GDP (i.e. improvements in the overall economic productivity of energy use). That energyGDP elasticities vary by end-use sector is consistent with the energy mix evolving as economies grow. In particular, the share of residences and agriculture tends to fall.

Our results also identify roles played by factors such as fuel prices, climate, population, and land area in explaining energy use. Other things equal, countries with higher gasoline prices tend to use less energy, countries with cold winters tend to use more energy, more denselypopulated countries use less energy for transport, and more spacious countries use more energy for agriculture. Conditional convergence in per capita energy use occurs at around 2.3\% per annum, similar to the rate for per capita GDP reported by Barro (2015).

Many of our results are in line with the expectations of earlier authors. For example, Ang (1987) concluded that the GDP elasticity of commercial fuels should be higher than that of non-commercial fuels. Other results help to update earlier expectations. For example, we find no evidence to support the fairly common (e.g. Jakob et al., 2012) expectation that the energy-GDP elasticity will be lower at higher incomes. We find the opposite, in large part due to lower dependence on (GDP-inelastic) primary solid biofuels in higher-income countries.

Looking to the future, our results suggest that economic growth is likely to continue to place upward pressure on energy use, particularly in the transport, industry, and services sectors, and also for energy transformation processes such as electricity generation. At the same time, other factors - such as time-specific common technology effects, or energy price increases can exert downward pressure on energy use. Trends to watch include robotification, the move to electric vehicles, and further improvements in low-emission technologies. The third of these could allow faster energy use growth by reducing the link between energy services and adverse environmental outcomes. 


\section{References}

Adams, F.G., Miovic, P., 1968. On relative fuel efficiency and the output elasticity of energy consumption in Western Europe. Journal of Industrial Economics 17(1), 41-56.

Adeyemi, O.I., Hunt, L.C., 2007. Modelling OECD industrial energy demand: Asymmetric price responses and energy-saving technical change. Energy Economics 29, 693-709.

Adeyemi, O.I., Hunt, L.C., 2014. Accounting for asymmetric price responses and underlying energy demand trends in OECD industrial energy demand. Energy Economics 45, 435-444.

Ang, B.W., 1987. Energy-output ratios and sectoral energy use: The case of Southeast Asian countries. Energy Policy 15(3), 262-282.

Ang, B.W., 1991. A statistical analysis of energy coefficients. Energy Economics 13(2), 93110.

Anjum Z., Burke, P.J., Gerlagh, R., Stern, D.I., 2014. Modeling the emissions-income relationship using long-run growth rates. CCEP Working Paper 1403.

Arseneau, D.M., 2012. Explaining the energy consumption portfolio in a cross-section of countries: Are the BRICs different? Law and Business Review of the Americas 18(4), 553584.

Baltagi, B.H., 2008. Econometric Analysis of Panel Data. $4^{\text {th }}$ ed. West Sussex, UK: John Wiley \& Sons.

Baltagi, B.H., Griffin, J.M., 1983. Gasoline demand in the OECD: An application of pooling and testing procedures. European Economic Review 22(2), 117-137.

Baltagi, B.H., Griffin, J.M., 1984. Short and long run effects in pooled models. International Economic Review 25(3), 631-645.

Barro, R.J., 2015. Convergence and modernisation. Economic Journal 125(585), 911-942.

Brookes, L.G., 1972. More on the output elasticity of energy consumption. Journal of Industrial Economics, 21(1), pp. 83-92.

Bruns S., Gross, C. 2013. What if energy time series are not independent? Implications for energy-GDP causality analysis. Energy Economics, 40, 753-759.

Bruns, S., Gross, C., Stern, D.I., 2014. Is there really Granger causality between energy use and output? Energy Journal 35(4), 101-134.

Burke, P.J., 2010. Income, resources, and electricity mix. Energy Economics 32(3), 616-626.

Burke, P.J., 2013. The national-level energy ladder and its carbon implications. Environment and Development Economics 18(4), 484-503. 
Burke, P.J., Dundas, G., 2015. Female labor force participation and household dependence on biomass energy: Evidence from national longitudinal data. World Development 67, 424-437.

Burke, P.J., Nishitateno, S., 2013. Gasoline prices, gasoline consumption, and new-vehicle fuel economy: Evidence for a large sample of countries. Energy Economics 36, 363-370.

Burke, P.J., Shahiduzzaman, M., Stern, D.I., 2015. Carbon dioxide emissions in the short run: The rate and sources of economic growth matter. Global Environmental Change 33, 109121.

Chenery, H.B. Syrquin, M., 1975. Patterns of Development, 1950-1970. London: Oxford University Press.

Csereklyei Z., Rubio Varas, M.d.M., Stern, D.I., 2016. Energy and economic growth: The stylized facts. Energy Journal 37(2), 223-255.

Csereklyei, Z., Stern, D.I., 2015. Global energy use: Decoupling or convergence? Energy Economics 51, 633-641.

De Boef, S., Keele, L., 2008. Taking time seriously. American Journal of Political Science 52(1), 184-200.

Easterly, W.R., 2001. Global Development Network Growth Database. http://go.worldbank.org/ZSQKYFU6J0.

Gao, Y.-X., Liao, H., Burke, P.J., Wei, Y.-M., 2015. Road transport energy consumption in the G7 and BRICS: 1973-2010. International Journal of Global Energy Issues 38(4-5-6), 342-356.

Harris, I., Jones, P.D., Osborn, T.J., Lister, D.H., 2014. Updated high resolution grids of monthly climatic observations - the CRU TS3.10 Dataset. International Journal of Climatology 34, 623-642.

Hauk, W.R. Jr., Wacziarg, R., 2009. A Monte Carlo study of growth regressions. Journal of Economic Growth 14, 103-147.

Herrerias, M.J., 2012. World energy intensity convergence revisited: A weighted distribution dynamics approach. Energy Policy 49, 383-399.

Heston, A., Summers, R., Aten, B., 2012. Penn World Table Version 7.1. University of Pennsylvania: Center for International Comparisons of Production, Income and Prices, http://www.rug.nl/research/ggdc/data/pwt/pwt-7.1.

Hurwicz, L., 1950. Least-squares bias in time series. In Koopmans, T.C., Statistical Inference in Dynamic Economic Models, 365-383. New York, NY: Wiley.

International Energy Agency, 2016. World Energy Statistics and Balances. Paris, France: International Energy Agency. 
Jakob, M., Haller, M., Marschinski, R., 2012. Will history repeat itself? Economic convergence and convergence in energy use patterns. Energy Economics 34(1), 95-104.

Judson, R.A., Schmalensee, R., Stoker, T.M., 1999. Economic development and the structure of the demand for commercial energy. Energy Journal 20(2), 29-57.

Kuznets, S., 1971. Economic Growth of Nations: Total Output and Production Structure. Cambridge, MA: Harvard University Press.

Lescaroux, F., 2011. Dynamics of final sectoral energy demand and aggregate energy intensity. Energy Policy 39, 66-82.

Lescaroux, F., 2013. Industrial energy demand, a forecasting model based on an index decomposition of structural and efficiency effects. OPEC Energy Review 37(4), 477-502.

Liddle, B., 2010. Revisiting world energy intensity convergence for regional differences. Applied Energy 87, 3218-3225.

Liddle, B., Lung, S., 2015. Revisiting energy consumption and GDP causality: Importance of a priori hypothesis testing, disaggregated data, and heterogeneous panels. Applied Energy 142, 44-55.

Medlock, K.B. III, Soligo, R., 2001. Economic development and end-use energy demand. Energy Journal 22(2), 77-105.

Miketa, A., Mulder, P., 2005. Energy productivity across developed and developing countries in 10 manufacturing sectors: Patterns of growth and convergence. Energy Economics 27, 429-453.

Mulder, P., de Groot, H.L.F., 2007. Sectoral energy- and labour-productivity convergence. Environmental and Resource Economics 36, 85-112.

Mulder, P., de Groot, H.L.F., 2012. Structural change and convergence of energy intensity across OECD countries, 1970-2005. Energy Economics 34, 1910-1921.

Mulder, P., de Groot, H.L.F., Pfeiffer, B., 2014. Dynamics and determinants of energy intensity in the service sector: A cross-country analysis, 1980-2005, Ecological Economics 100, 1-15.

Nakićenović, N., Grübler, A., McDonald, A., 1998. Global Energy Perspectives. Cambridge, UK: Cambridge University Press.

Ordás Criado, C., Valente, S., Stengos, T., 2011. Growth and pollution convergence: Theory and evidence. Journal of Environmental Economics and Management 62, 199-214.

Pesaran, M.H., Smith, R., 1995. Estimating long-run relationships from dynamic heterogeneous panels. Journal of Econometrics 68(1), 79-113.

Pirotte, A., 1999. Convergence of the static estimation toward the long run effects of dynamic panel data models. Economics Letters 63(2), 151-158. 
Pirotte, A., 2003. Convergence of the static estimation toward the long run effects of dynamic panel data models: A labour demand illustration. Applied Economics Letters 10(13), 843847.

Schäfer, A., 2005. Structural change in energy use. Energy Policy 33(4), 429-437.

Smil, V., 2000. Energy in the twentieth century: Resources, conversions, costs, uses, and consequences. Annual Review of Energy and the Environment 25, 21-51.

Stern, D.I., 2010. Between estimates of the emissions-income elasticity. Ecological Economics 69(11): 2173-2182.

Tahvonen, O., Salo, S., 2001. Economic growth and transitions between renewable and nonrenewable energy resources. European Economic Review 45(8), 1379-1398.

van Benthem, A., 2015. Energy leapfrogging. Journal of the Association of Environmental and Resource Economists 2(1): 93-132.

van Benthem, A., Romani, M., 2009. Fuelling growth: What drives energy demand in developing countries? Energy Journal 30(3), 91-114.

World Bank, 2015. World Development Indicators. http://data.worldbank.org/datacatalog/world-development-indicators. 


\section{Appendix}

\section{A1. Variable definitions}

Final energy use by residences: Total final consumption of energy by households, excluding for transport, in oil-equivalent terms. Source: IEA (2016).

Final energy use by agriculture: Total final consumption of energy by the agriculture, hunting, forestry, and fishing sectors in oil-equivalent terms. Covers ISIC Rev. 4 Divisions 01-03. Source: IEA (2016).

Final energy use by transport: Total final consumption of energy by all transport forms, in oil-equivalent terms. Covers ISIC Rev. 4 Divisions 49-51. Source: IEA (2016).

Final energy use by industry: Total final consumption of energy by industry, in oil-equivalent terms. Industry includes iron and steel; chemical and petrochemical; non-ferrous metals; nonmetallic minerals; transport equipment; machinery; mining and quarrying; food and tobacco; paper, pulp, and print; wood and wood products; construction; textile and leather; and nonspecified. Source: IEA (2016).

Final energy use by services: Total final consumption of energy by the commercial and public services sector in oil-equivalent terms. This is a broad category that includes repair and installation of machinery and equipment; water, sewerage, and waste services; wholesale and retail trade; warehousing and postal services; accommodation and food services; information and communication; finance and insurance; real estate; professional, scientific and technical activities; administrative and support services; public administration; education; health and social work; arts, entertainment, and recreation; and other. Source: IEA (2016).

Other energy use: Total primary energy use minus final energy use in the above five categories. Includes primary energy lost in transformation (e.g. the generation of electricity) and distribution; primary energy used by the energy industry itself; other final energy use not allocated to one of the above sectors; use of non-biomass fuels for non-energy purposes; and transfers and statistical differences. Source: IEA (2016).

Total energy use: Total primary energy supply (TPES) in oil-equivalent terms. This is the total use of all energy types. This is a broader concept than total final consumption (TFC) of energy because it includes energy used in transformation and distribution processes, energy consumed by the energy industry itself, and additional transfers and statistical differences. Source: IEA (2016).

** Unless otherwise mentioned, the above seven categories include primary solid biofuels. In additional specifications we deduct use of primary solid biofuels from each measure (e.g. Table 3). This involves subtracting two IEA categories: "primary solid biofuels" and "nonspecified primary biofuels and waste”. The IEA (2016) defines primary solid biofuels as "any 
plant matter used directly as fuel or converted into other forms before combustion. This covers a multitude of woody materials generated by industrial process or provided directly by forestry and agriculture (firewood, wood chips, bark, sawdust, shavings, chips, sulphite lyes also known as black liquor, animal materials/wastes and other solid biofuels)". We have not deducted charcoal use. $* *$

Electricity use by residences: Total consumption of electricity by households, excluding for transport, in oil-equivalent terms. Source: IEA (2016).

Electricity use by agriculture: Total consumption of electricity by the agriculture, hunting, forestry, and fishing sectors in oil-equivalent terms. Covers ISIC Rev. 4 Divisions 01-03. Source: IEA (2016).

Electricity use by transport: Total consumption of electricity by all transport forms, in oilequivalent terms. Covers ISIC Rev. 4 Divisions 49-51. Source: IEA (2016).

Electricity use by industry: Total final consumption of electricity by industry, in oilequivalent terms. Industry is defined above. Source: IEA (2016).

Electricity use by services: Total final consumption of electricity by the commercial and public services sector in oil-equivalent terms. Services is defined above. Source: IEA (2016).

Electricity use (other): Total final consumption of electricity by other users in oil-equivalent terms. This category is named "Non-specified (other)" in the IEA data. Source: IEA (2016).

Electricity use total: Total final consumption of electricity by all sectors, in oil-equivalent terms. Source: IEA (2016).

GDP per capita: PPP-converted GDP per capita (chain series) at 2005 constant prices. Source: Heston et al. (2012).

Gasoline price: Pump price of the most widely sold grade of road-sector gasoline, in \$US. Source: World Bank (2015).

Temperature (coldest month): Average temperature over each country's land area in that country's coldest month, in ${ }^{\circ} \mathrm{C}$. Source: Harris et al. (2014), data version CRU TS v3.22. See http://www.cru.uea.ac.uk/cru/data/hrg/.

Temperature (warmest month): Average temperature over each country's land area in that country’s warmest month, in ${ }^{\circ} \mathrm{C}$. Source: Harris et al. (2014), data version CRU TS v3.22. See http://www.cru.uea.ac.uk/cru/data/hrg/. 
Precipitation: Precipitation averaged over each country's land area and over the 12 months of the year, in millimeters. Source: Harris et al. (2014), data version CRU TS v3.22. See http://www.cru.uea.ac.uk/cru/data/hrg/.

Population: Total population, in people. This variable was used in the construction of the per capita energy/electricity use variables. Source: Heston et al. (2012).

Land area: Land area in square kilometers, excluding inland water bodies, national claims to continental shelf, and exclusive economic zones. Source: World Bank (2015).

Transition economy dummy: Equal to one for former transition economies, 0 otherwise. This measure focuses on former transition economies in our sample in Europe and Central Asia: Albania, Armenia, Azerbaijan, Belarus, Bosnia and Herzegovina, Bulgaria, Croatia, Czech Republic, Estonia, Georgia, Hungary, Kazakhstan, Kyrgyz Republic, Latvia, Lithuania, Macedonia FYR, Moldova, Montenegro, Poland, Romania, Russian Federation, Serbia, Slovak Republic, Slovenia, Tajikistan, Turkmenistan, Ukraine, and Uzbekistan. Source: Easterly (2001).

Region dummies: These dummies cover six of the seven World Bank (2015) regions. The base region (i.e. excluded region) is East Asia and the Pacific. 
A2. List of countries in the 132-country sample

\begin{tabular}{|c|c|c|c|c|c|}
\hline Low income (11) & Middle income (71) & & & High income (50) & \\
\hline Congo, Dem. Rep. & Angola & Guatemala & Pakistan & Austria* & Lithuania \\
\hline Eritrea & Armenia & Honduras & Panama & Bahrain & Luxembourg* \\
\hline Mozambique & Bangladesh & Indonesia & Peru & Brunei Darussalam & Netherlands* \\
\hline Nepal & Belarus & Iran, Islamic Rep. & Philippines & Canada* & New Zealand \\
\hline Niger & Bolivia & Iraq & Romania & Chile & Norway* \\
\hline Zimbabwe & Brazil & Kazakhstan & South Africa & Czech Republic & Portugal* \\
\hline & Bulgaria & Kenya & Sri Lanka & Denmark* & Qatar \\
\hline & Cameroon & Kyrgyz Republic & Sudan & Estonia & Russian Federation \\
\hline & China & Lebanon & Syrian Arab Republic & Finland* & Saudi Arabia \\
\hline & Colombia & Libya & Tajikistan & France* & Singapore \\
\hline & Congo, Rep. & Macedonia, FYR & Thailand & Germany* & Slovak Republic \\
\hline & Ecuador & Mongolia & Uzbekistan & Ireland* & United Arab Emirates \\
\hline & Egypt, Arab Rep. & Montenegro & Vietnam & Israel & United Kingdom* \\
\hline & El Salvador & Morocco & Yemen, Rep. & Italy* & United States* \\
\hline & & Namibia & Zambia & Japan* & Uruguay \\
\hline & & & & Korea, Rep. & Venezuela, RB \\
\hline
\end{tabular}

Source: World Bank (2015). Country classifications are as at August 2015. OECD23 countries are indicated by a *. 


\section{A3. Descriptive statistics, 2010 cross-section}

\begin{tabular}{|c|c|c|c|c|c|c|c|}
\hline \multirow{3}{*}{ Per-capita energy use (kgoe per year) by } & \multirow[t]{2}{*}{ Mean } & \multirow{2}{*}{$\begin{array}{l}\text { Standard } \\
\text { deviation }\end{array}$} & \multirow[t]{2}{*}{ Minimum } & \multirow[t]{2}{*}{ Maximum } & \\
\hline & & & & & \multicolumn{2}{|c|}{$\begin{array}{l}\text { Mean for income group } \\
\text { Low Middle }\end{array}$} & High \\
\hline & & & & & & & \\
\hline Residences $^{\mathrm{F}}$ & 361.2 & 265.3 & 33.3 & $1,222.0$ & 249.1 & 218.9 & 587.9 \\
\hline Agriculture $^{\mathrm{F}}$ & 39.6 & 77.6 & 0.0 & 788.7 & 8.9 & 22.3 & 70.9 \\
\hline Transport ${ }^{\mathrm{F}}$ & 470.6 & 611.4 & 7.9 & $4,392.0$ & 38.2 & 214.4 & 929.4 \\
\hline Industry ${ }^{\mathrm{F}}$ & 494.7 & 827.5 & 2.0 & $5,542.3$ & 33.1 & 202.3 & $1,011.4$ \\
\hline Services $^{\mathrm{F}}$ & 172.0 & 220.2 & 0.0 & $1,273.4$ & 9.9 & 65.6 & 358.8 \\
\hline Other & $1,187.8$ & $2,357.0$ & 4.1 & $21,839.4$ & 57.0 & 465.8 & $2,461.8$ \\
\hline Total & $2,725.8$ & $3,832.3$ & 127.9 & $32,871.7$ & 396.2 & $1,189.3$ & $5,420.2$ \\
\hline \multicolumn{8}{|c|}{ Per-capita energy use (kgoe per year), excluding primary solid biofuels, by } \\
\hline Residences $^{\mathrm{F}}$ & 270.8 & 268.8 & 3.3 & $1,222.0$ & 32.8 & 131.3 & 521.2 \\
\hline Agriculture ${ }^{\mathrm{F}}$ & 37.7 & 76.9 & 0.0 & 788.7 & 4.8 & 21.6 & 67.8 \\
\hline Transport ${ }^{\mathrm{F}}$ & 470.6 & 611.4 & 7.9 & $4,392.0$ & 38.2 & 214.4 & 929.4 \\
\hline Industry $^{\mathrm{F}}$ & 461.0 & 818.6 & 2.0 & $5,542.3$ & 15.3 & 184.8 & 951.3 \\
\hline Services $^{\mathrm{F}}$ & 169.0 & 220.1 & 0.0 & $1,273.4$ & 4.9 & 63.1 & 355.5 \\
\hline Other & $1,141.0$ & $2,364.3$ & $-63.2^{\mathrm{a}}$ & $21,839.4$ & $-7.3^{\mathrm{a}}$ & 426.9 & $2,407.6$ \\
\hline Total & $2,550.0$ & $3,855.1$ & 17.8 & $32,871.7$ & 88.7 & $1,042.1$ & $5,232.8$ \\
\hline GDP per capita (I\$ per year, 2005 prices) & $15,472.9$ & $18,049.5$ & 240.5 & $136,248.1$ & 841.5 & $6,292.7$ & $31,727.8$ \\
\hline Gasoline price (US\$ per liter) & 1.2 & 0.5 & 0.0 & 2.5 & 1.3 & 1.1 & 1.4 \\
\hline Temperature (coldest month) $\left({ }^{\circ} \mathrm{C}\right)$ & 9.5 & 13.1 & -26.5 & 26.3 & 20.5 & 12.4 & 3.1 \\
\hline Temperature (warmest month) $\left({ }^{\circ} \mathrm{C}\right)$ & 25.3 & 5.5 & 10.1 & 38.2 & 27.5 & 26.5 & 23.1 \\
\hline Precipitation (millimeters per year) & $1,097.2$ & 858.8 & 30.1 & $3,830.3$ & 993.1 & $1,207.9$ & 962.8 \\
\hline Population (million people) & 49.2 & 157.8 & 0.3 & $1,330.1$ & 28.6 & 68.5 & 26.4 \\
\hline Land (thousand square kilometers) & 907.7 & $2,184.3$ & 0.3 & $16,376.9$ & 652.8 & 817.7 & $1,091.4$ \\
\hline Transition dummy & 0.2 & 0.4 & 0.0 & 1.0 & 0.0 & 0.3 & 0.2 \\
\hline
\end{tabular}

Notes: kgoe = kilograms oil equivalent. The data cover 132 countries. The income groups follow World Bank (2015)

${ }^{a}:$ Negative values are dropped from the estimations as the logarithm is undefined. 


\section{A4. Between estimates, 1960-2010}

\begin{tabular}{|c|c|c|c|c|c|c|c|}
\hline & $\begin{array}{l}(1) \\
\text { Residences }\end{array}$ & $\begin{array}{l}\text { (2) } \\
\text { Agriculture }^{\mathrm{F}}\end{array}$ & $\begin{array}{l}\text { (3) } \\
\text { Transport }^{\mathrm{F}}\end{array}$ & $\begin{array}{l}4) \\
\text { Industry }{ }^{\mathrm{F}}\end{array}$ & $\begin{array}{l}\text { (5) } \\
\text { Services }{ }^{\mathrm{F}}\end{array}$ & $\begin{array}{l}6) \\
\text { Other }\end{array}$ & $\begin{array}{l}7) \\
\text { Total } \\
\end{array}$ \\
\hline \multicolumn{8}{|c|}{ Panel A: Ln per capita energy use } \\
\hline Ln GDP per capita & $\begin{array}{l}0.37 * * * \\
(0.07)\end{array}$ & $\begin{array}{l}0.57 * * * \\
(0.16)\end{array}$ & $\begin{array}{l}0.95^{* * * *} \\
(0.05)\end{array}$ & $\begin{array}{l}0.93 * * * \\
(0.09)\end{array}$ & $\begin{array}{l}1.16^{* * * *} \\
(0.12)\end{array}$ & $\begin{array}{l}1.01^{* * * *} \\
(0.07)\end{array}$ & $\begin{array}{l}0.78 * * * \\
(0.05)\end{array}$ \\
\hline$R^{2}$ & 0.49 & 0.60 & 0.92 & 0.78 & 0.70 & 0.85 & 0.87 \\
\hline \multicolumn{8}{|c|}{ Panel B: Ln per capita energy use excluding primary solid biofuels } \\
\hline Ln GDP per capita & $\begin{array}{l}0.69 * * * \\
(0.07)\end{array}$ & $\begin{array}{l}0.59 * * * \\
(0.15)\end{array}$ & $\begin{array}{l}0.95 * * * \\
(0.05)\end{array}$ & $\begin{array}{l}1.10^{* * * *} \\
(0.08)\end{array}$ & $\begin{array}{l}1.21 * * * \\
(0.11)\end{array}$ & $\begin{array}{l}1.07 * * * \\
(0.10)\end{array}$ & $\begin{array}{l}1.02 * * * \\
(0.05)\end{array}$ \\
\hline$R^{2}$ & 0.82 & 0.62 & 0.92 & 0.85 & 0.79 & 0.84 & 0.92 \\
\hline \multicolumn{8}{|c|}{ Panel C: Ln per capita final electricity use } \\
\hline Ln GDP per capita & $\begin{array}{l}0.90 * * * \\
(0.07)\end{array}$ & $\begin{array}{l}0.58^{* * *} \\
(0.16)\end{array}$ & $\begin{array}{l}1.32 * * * \\
(0.21)\end{array}$ & $\begin{array}{l}1.01 * * * \\
(0.10)\end{array}$ & $\begin{array}{l}1.21 * * * \\
(0.09)\end{array}$ & $\begin{array}{l}-0.08 \\
(0.71)\end{array}$ & $\begin{array}{l}0.99 * * * \\
(0.07)\end{array}$ \\
\hline$R^{2}$ & 0.87 & 0.55 & 0.72 & 0.78 & 0.85 & 0.13 & 0.87 \\
\hline Countries & 132 & 121 & 132 & 132 & 131 & 132 & 132 \\
\hline Observations (maximum) & 4,840 & 2,266 & 4,840 & 4,814 & 4,487 & 4,840 & 4,840 \\
\hline
\end{tabular}

Notes: ***,**, and * indicate statistical significance at 1, 5, and 10\%. Standard errors are in parentheses. All estimates control for Ln(Gasoline price $_{2010}$ ); Temperature (coldest month); Temperature (warmest month); Ln(Precipitation); Ln(Population); Ln(Land); transition economy dummy; region dummies. Coefficients on controls not reported. Some samples in Panels B and C are reduced below the displayed totals due to instances of $\ln (0)$. The agriculture sample has been restricted to 1990-2010 due to data irregularities for early years. Panel C: "Other" and "Total” are for final electricity use (not primary). 
A5. 39-year growth rates estimates, 1971-2010

\begin{tabular}{|c|c|c|c|c|c|c|c|c|c|c|c|c|}
\hline \multirow{3}{*}{$\begin{array}{l}\text { Dependent variable: } \\
\text { 39-year annual average growth } \\
\text { rate of per capita ... }\end{array}$} & $(1)$ & $(2)$ & $(3)$ & $(4)$ & $(5)$ & (6) & $(7)$ & $(8)$ & $(9)$ & $(10)$ & $(11)$ & $(12)$ \\
\hline & \multicolumn{6}{|c|}{ energy use by ... } & \multicolumn{2}{|c|}{$\begin{array}{l}\text { energy use excluding } \\
\text { primary solid biofuels by }\end{array}$} & \multicolumn{4}{|c|}{ electricity use (final) by ... } \\
\hline & Residences $^{\mathrm{F}}$ & Transport ${ }^{\mathrm{F}}$ & Industry ${ }^{\mathrm{F}}$ & Services ${ }^{\mathrm{F}}$ & Other & Total & Residences ${ }^{\mathrm{F}}$ & Total & Residences & Industry & Services & Total \\
\hline $\begin{array}{l}\text { GDP per capita growth rate } \text { rea }_{39} \\
\text { year }\end{array}$ & $\begin{array}{l}0.08 \\
(0.11)\end{array}$ & $\begin{array}{l}0.72^{* * *} \\
(0.10)\end{array}$ & $\begin{array}{l}0.72 * * * \\
(0.24)\end{array}$ & $\begin{array}{l}0.79 * * * \\
(0.24)\end{array}$ & $\begin{array}{l}0.61^{* * *} \\
(0.18)\end{array}$ & $\begin{array}{l}0.47 * * * \\
(0.12)\end{array}$ & $\begin{array}{l}0.44^{* * *} \\
(0.11)\end{array}$ & $\begin{array}{l}0.74 * * * \\
(0.13)\end{array}$ & $\begin{array}{l}0.68 * * * \\
(0.17)\end{array}$ & $\begin{array}{l}0.79 * * * \\
(0.23)\end{array}$ & $\begin{array}{l}1.11 * * * \\
(0.22)\end{array}$ & $\begin{array}{l}0.72^{* * *} \\
(0.15)\end{array}$ \\
\hline $\begin{array}{l}\text { GDP per capita growth rate }{ }_{39-} \\
\text { year }{ }^{2} \text { Ln GDP per capita } 1971 ; \\
\text { sample demeaned }\end{array}$ & $\begin{array}{l}0.04 \\
(0.05)\end{array}$ & $\begin{array}{l}0.03 \\
(0.05)\end{array}$ & $\begin{array}{l}0.17^{*} \\
(0.10)\end{array}$ & $\begin{array}{l}0.10 \\
(0.12)\end{array}$ & $\begin{array}{l}-0.15 \\
(0.10)\end{array}$ & $\begin{array}{l}0.06 \\
(0.06)\end{array}$ & $\begin{array}{l}-0.01 \\
(0.04)\end{array}$ & $\begin{array}{l}-0.04 \\
(0.06)\end{array}$ & $\begin{array}{l}0.02 \\
(0.08)\end{array}$ & $\begin{array}{l}-0.06 \\
(0.15)\end{array}$ & $\begin{array}{l}0.15 \\
(0.16)\end{array}$ & $\begin{array}{l}-0.02 \\
(0.07)\end{array}$ \\
\hline Ln GDP per capita 1971 & $\begin{array}{l}0.005^{* *} \\
(0.002)\end{array}$ & $\begin{array}{l}0.013 * * * \\
(0.002)\end{array}$ & $\begin{array}{l}0.006 \\
(0.004)\end{array}$ & $\begin{array}{l}0.016 * * * \\
(0.006)\end{array}$ & $\begin{array}{l}0.024 * * * \\
(0.004)\end{array}$ & $\begin{array}{l}0.011 * * * \\
(0.003)\end{array}$ & $\begin{array}{l}0.014 * * * \\
(0.002)\end{array}$ & $\begin{array}{l}0.016 * * * \\
(0.004)\end{array}$ & $\begin{array}{l}0.012 * * \\
(0.005)\end{array}$ & $\begin{array}{l}0.006 \\
(0.005)\end{array}$ & $\begin{array}{l}0.020^{* *} \\
(0.008)\end{array}$ & $\begin{array}{l}0.011 * * * \\
(0.004)\end{array}$ \\
\hline $\begin{array}{l}\text { Ln Energy or electricity use } \\
\text { per capita in that sector }{ }_{1971}\end{array}$ & $\begin{array}{l}-0.019 * * * \\
(0.003)\end{array}$ & $\begin{array}{l}-0.019 * * * \\
(0.001)\end{array}$ & $\begin{array}{l}-0.016^{* * *} \\
(0.002)\end{array}$ & $\begin{array}{l}-0.021 * * * \\
(0.002)\end{array}$ & $\begin{array}{l}-0.021^{* * *} \\
(0.002)\end{array}$ & $\begin{array}{l}-0.018 * * * \\
(0.003)\end{array}$ & $\begin{array}{l}-0.021^{* * *} \\
(0.001)\end{array}$ & $\begin{array}{l}-0.018 * * * \\
(0.003)\end{array}$ & $\begin{array}{l}-0.017 * * * \\
(0.002)\end{array}$ & $\begin{array}{l}-0.012 * * * \\
(0.002)\end{array}$ & $\begin{array}{l}-0.022 * * * \\
(0.002)\end{array}$ & $\begin{array}{l}-0.016 * * * \\
(0.002)\end{array}$ \\
\hline Ln Gasoline price 2010 & $\begin{array}{l}-0.005 \\
(0.003)\end{array}$ & $\begin{array}{l}-0.008^{* * *} \\
(0.003)\end{array}$ & $\begin{array}{l}-0.011^{* * *} \\
(0.002)\end{array}$ & $\begin{array}{l}-0.005 \\
(0.003)\end{array}$ & $\begin{array}{l}-0.002 \\
(0.003)\end{array}$ & $\begin{array}{l}-0.007 * * * \\
(0.002)\end{array}$ & $\begin{array}{l}-0.004 * * \\
(0.002)\end{array}$ & $\begin{array}{l}-0.007 * * * \\
(0.002)\end{array}$ & $\begin{array}{l}-0.004^{* *} \\
(0.002)\end{array}$ & $\begin{array}{l}-0.006 * * \\
(0.002)\end{array}$ & $\begin{array}{l}-0.003 \\
(0.002)\end{array}$ & $\begin{array}{l}-0.004^{* *} \\
(0.002)\end{array}$ \\
\hline $\begin{array}{l}\text { Temperature (coldest } \\
\text { month) } \text { 39-vear average }\end{array}$ & $\begin{array}{l}-0.000^{*} \\
(0.000)\end{array}$ & $\begin{array}{l}-0.000 \\
(0.000)\end{array}$ & $\begin{array}{l}0.000 \\
(0.000)\end{array}$ & $\begin{array}{l}-0.001 \\
(0.001)\end{array}$ & $\begin{array}{l}0.000 \\
(0.000)\end{array}$ & $\begin{array}{l}-0.000 \\
(0.000)\end{array}$ & $\begin{array}{l}-0.0004^{*} \\
(0.0002)\end{array}$ & $\begin{array}{l}-0.000 \\
(0.000)\end{array}$ & $\begin{array}{l}-0.001 * * \\
(0.000)\end{array}$ & $\begin{array}{l}-0.000 \\
(0.000)\end{array}$ & $\begin{array}{l}-0.001 * * * \\
(0.000)\end{array}$ & $\begin{array}{l}-0.000 \\
(0.000)\end{array}$ \\
\hline $\begin{array}{l}\text { Temperature (warmest } \\
\text { month) }\end{array}$ & $\begin{array}{l}-0.000 \\
(0.000)\end{array}$ & $\begin{array}{l}0.001 \\
(0.000)\end{array}$ & $\begin{array}{l}-0.001 \\
(0.001)\end{array}$ & $\begin{array}{l}0.000 \\
(0.001)\end{array}$ & $\begin{array}{l}-0.000 \\
(0.001)\end{array}$ & $\begin{array}{l}-0.000 \\
(0.000)\end{array}$ & $\begin{array}{l}0.000 \\
(0.000)\end{array}$ & $\begin{array}{l}0.000 \\
(0.000)\end{array}$ & $\begin{array}{l}0.001^{* *} \\
(0.000)\end{array}$ & $\begin{array}{l}-0.001 \\
(0.001)\end{array}$ & $\begin{array}{l}0.002^{* * * *} \\
(0.000)\end{array}$ & $\begin{array}{l}0.000 \\
(0.001)\end{array}$ \\
\hline Controls and region dummies & Yes & Yes & Yes & Yes & Yes & Yes & Yes & Yes & Yes & Yes & Yes & Yes \\
\hline$R^{2}$ & 0.84 & 0.77 & 0.77 & 0.77 & 0.73 & 0.81 & 0.89 & 0.82 & 0.88 & 0.68 & 0.89 & 0.85 \\
\hline \multicolumn{13}{|c|}{ 39-year growth rates elasticity evaluated at $x^{\text {th }}$ percentile of GDP per capita ${ }_{1971} \ldots$} \\
\hline $25^{\text {th }}$ & 0.04 & $0.70 * * *$ & $0.57^{* *}$ & $0.70 * * *$ & $0.74 * * *$ & $0.42 * * *$ & $0.45 * * *$ & $0.77 * * *$ & $0.66^{* * *}$ & $0.84 * * *$ & $0.99 * * *$ & $0.74 * * *$ \\
\hline $75^{\text {th }}$ & 0.12 & $0.75^{* * *}$ & $0.90 * * *$ & $0.90 * * *$ & $0.45^{*}$ & $0.53^{* * *}$ & $0.44 * * *$ & $0.70 * * *$ & $0.71 * * *$ & $0.73 * *$ & $1.27 * * *$ & $0.71 * * *$ \\
\hline Long-run elasticity & $0.24 * *$ & $0.68^{* * *}$ & $0.37 *$ & $0.75^{* * *}$ & $1.16^{* * *}$ & $0.60^{* * *}$ & $0.70^{* * *}$ & $0.92^{* * *}$ & $0.70^{* * *}$ & 0.50 & $0.92 * * *$ & $0.68 * * *$ \\
\hline Observations & 97 & 97 & 96 & 83 & 97 & 97 & 97 & 97 & 87 & 91 & 74 & 97 \\
\hline
\end{tabular}

Notes: ***, **, and * indicate statistical significance at 1,5 , and $10 \%$. Robust standard errors are in parentheses. The standard error for the long-run elasticity was calculated using the delta method.

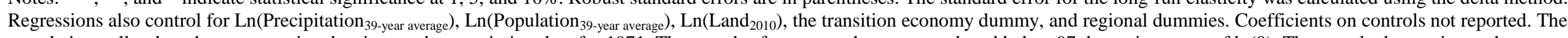
sample is smaller than the cross-sectional estimates due to missing data for 1971. The samples for some columns are reduced below 97 due to instances of ln(0). The sample demeaning and

percentiles are for the 97-country sample. "39-year average” refers to the period 1972-2010. Growth rates are annual averages, calculated using differenced logs divided by 39; 0.01 approximately equals $1 \%$ average annual growth. The long-run elasticity is evaluated for a future GDP per capita growth rate of zero. 